\title{
Ostracods (Crustacea) as shelf to basin indicators: evidence from Late Devonian Yangdi and Nandong sections in Guangxi, South China
}

\author{
Junjun Song ${ }^{1,2,3}$, Sylvie Crasquin ${ }^{3}$, and Yiming Gong ${ }^{1}$ \\ ${ }^{1}$ State Key Laboratory of Biogeology and Environmental Geology, School of Earth Sciences, \\ China University of Geosciences, Wuhan 430074, China \\ ${ }^{2}$ Key Laboratory of Economic Stratigraphy and Palaeogeography, Nanjing Institute of Geology and \\ Palaeontology, Chinese Academy of Sciences, Nanjing 210008, China \\ ${ }^{3}$ CR2P, MNHN-UPMC-CNRS, Sorbonne Universités, Université Pierre et Marie Curie, \\ T46-56, E.5, case 104, 75252 Paris CEDEX 05, France
}

Correspondence: Yiming Gong (ymgong@cug.edu.cn)

Published: 5 February 2018

\begin{abstract}
Forty-eight ostracod species belonging to 28 genera from the Late Devonian of Guangxi in South China are described and figured. The ostracod assemblage from the Nandong section can be attributed to the rhenana-linguiformis conodont zones. The ecological assemblages of ostracods from the Yangdi section correspond to a smooth-podocopid association accompanied by some pelagic entomozoids. This mixed assemblage is indicative of an environment of carbonate platform to slope during an ongoing regression. The ostracod faunas from the Nandong section are on the contrary composed of both pelagic and benthic ostracods and pelagic forms dominate in number of specimens suggesting a basin environment.
\end{abstract}

\section{Introduction}

Ostracods are one of the most widespread and diverse group of crustaceans since the Early Ordovician (Horne et al., 2002; Siveter, 2008). Devonian is a prosperous period for ostracods, particularly in marine environments from very shallow coastal seas to deep abyssal plains. With their great distribution, they play an important role in stratigraphic subdivisions and consequently for correlations (e.g. Lethiers, 1978, 1981; Casier, 1987, 2003, 2004, 2008). In addition, ostracods offer special insights into palaeoenvironmental and palaeogeographical reconstructions for their sensitivity to the ambient environments (i.e. salinity, bathymetry, temperature, hydrodynamics, oxygenation and nutrients, etc.) (Lethiers, 1981; Casier, 1985; Casier and Olempska, 2008; Olempska and Belka, 2010; Casier et al., 2011; Racheboeuf et al., 2012; Maillet et al., 2013; Song and Gong, 2015a, b, 2017; Song et al., 2017).

Systematic biostratigraphy and palaeoecology of the Early and Middle Devonian ostracods in South China have been well studied (e.g. Wang, 1979, 1986, 1987, 1988; Zhang, 1986, 1995; Wang et al., 1992; Wang and Liu, 1994). An entomozoacean zonation was established by Wang (1987, 2009) and a sinoleperditiine biostratigraphical sequence for the Devonian was summarized by Wang and Peng (2005). However, there are only a few studies on the Late Devonian ostracods from South China (Casier et al., 1997; Wang and Ma, 2007). This paper aims to provide a systematic description of some Late Devonian ostracods from the Yangdi and Nandong sections (Guangxi, South China) and discuss their biostratigraphical and palaeoecological values.

\section{Geological setting and section descriptions}

During the Late Palaeozoic, the South China Block has a $90^{\circ}$ anticlockwise position comparative to today. The palaeogeographic frame of South China consisted of the YangtzeCathysia continent and the southern South China Sea. The South China Block was subject of two transgressions from the southwest to the northeast during the Devonian. From the 


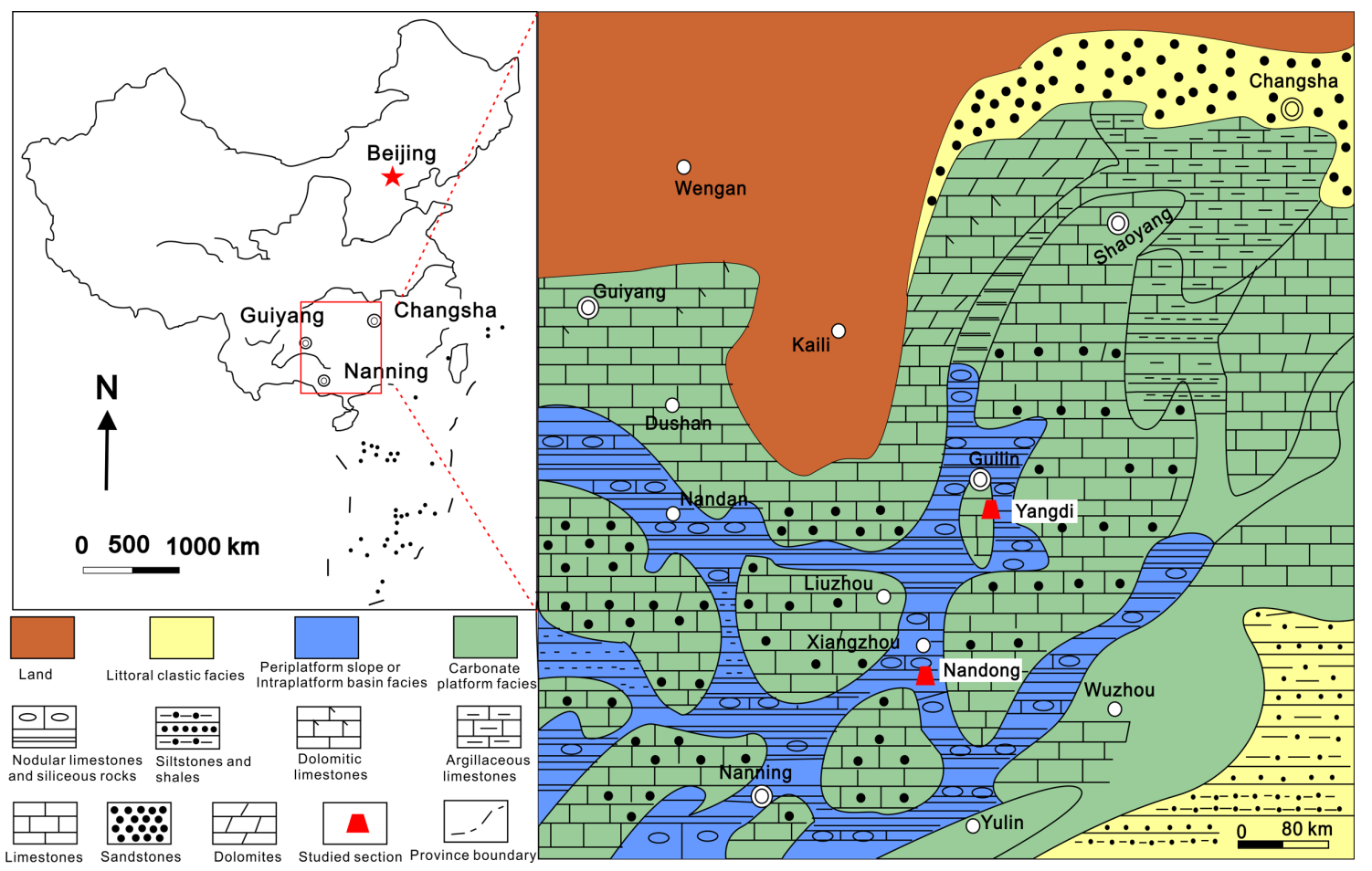

Figure 1. Late Devonian lithofacies and palaeogeography of South China (modified after Huang and Gong, 2016; Ma et al., 2016) with the locations of the studied sections.

late Emsian to the Famennian, the basement of the epicontinental sea of South China Block was cut by varied intersected rifts, developing into a complex palaeogeography of shallowwater platforms separated by deep-water basins (Dong, 1982; Ma and Bai, 2002) (Fig. 1). This special palaeogeographic pattern controlled the distribution of bio- and lithofacies ( $\mathrm{Ji}$, 1989; Hou et al., 1988). The basin or slope facies are distributed in a rift belt to the northeast and northwest and crosscut the carbonate platform facies. Benthic organisms (such as brachiopods, ostracods and corals) dominated in the shallow carbonate platform facies, while pelagic organisms (e.g. conodonts, ammonoids and some allegedly pelagic ostracods) preponderated in the deep basin facies (Ma, 2004).

The Yangdi section $\left(24^{\circ} 58.2^{\prime} \mathrm{N}, 110^{\circ} 22.8^{\prime} \mathrm{E}\right)$ is located along the road from Baoan to Yangdi, about $35 \mathrm{~km}$ southeast of Guilin city, Guangxi. It is a well-outcropped section with continuous deposition of the Late Devonian, which has been studied in detail for biostratigraphy, lithostratigraphy, chemostratigraphy and cyclostratigraphy (Ji, 1989; Gong et al., 1997, 2001, 2005; Wang, 1990; Ma and Bai, 2002; Chen et al., 2013). A reliable and high-resolution conodont biostratigraphy has been established in this section by Huang and Gong (2016). The Yangdi section displays a continuous sedimentation from the Frasnian to the Famennian with, from the bottom to the top, the Fuhe, Lazhutai, Xiangtian, and Wuzhishan formations (Ji, 1989; Ma and Bai, 2002). The lower and middle Frasnian is represented by two strati- graphic units, i.e. the Fuhe Formation and the Lazhutai Formation (see detailed descriptions in Ji, 1989; Ma and Bai, 2002). The Xiangtian Formation (28 m thick), which is dated to the late Frasnian, can be divided into three parts. The lower part is composed of grey to dark-grey thin-bedded wackestones intercalated with banded cherts (Beds 0-11); the middle part is about $2 \mathrm{~m}$ thick and characterized by darkgrey thick-bedded brecciated limestones (Bed 12); the upper part consists of grey argillaceous limestones intercalated with nodular limestones and dark-grey thin-bedded calcareous turbidites (Beds 13-41). The Wuzhishan Formation is mainly characterized by light-grey thick-bedded nodular limestones (Fig. 2).

The Nandong section is well exposed along a river close to Nandong Village, in Wuxuan County, Guangxi $\left(23^{\circ} 46^{\prime} 42.98^{\prime \prime} \mathrm{N}, 109^{\circ} 41^{\prime} 57.63^{\prime \prime} \mathrm{E}\right)$. This section has been studied previously for lithostratigraphy, biostratigraphy and geochemistry (Bai et al., 1994; Gong and Li, 2001; Huang, 2015). The Nandong section exhibits a continuous deposition from the Liujiang Formation to the Wuzhishan Formation (Fig. 3). The Liujiang Formation is made of grey thin-bedded siliceous rocks intercalated with argillaceous limestones. The lower part of the Wuzhishan Formation is characterized by grey nodular limestones, and the upper part is composed of dark-grey thin-bedded siliceous rocks. 


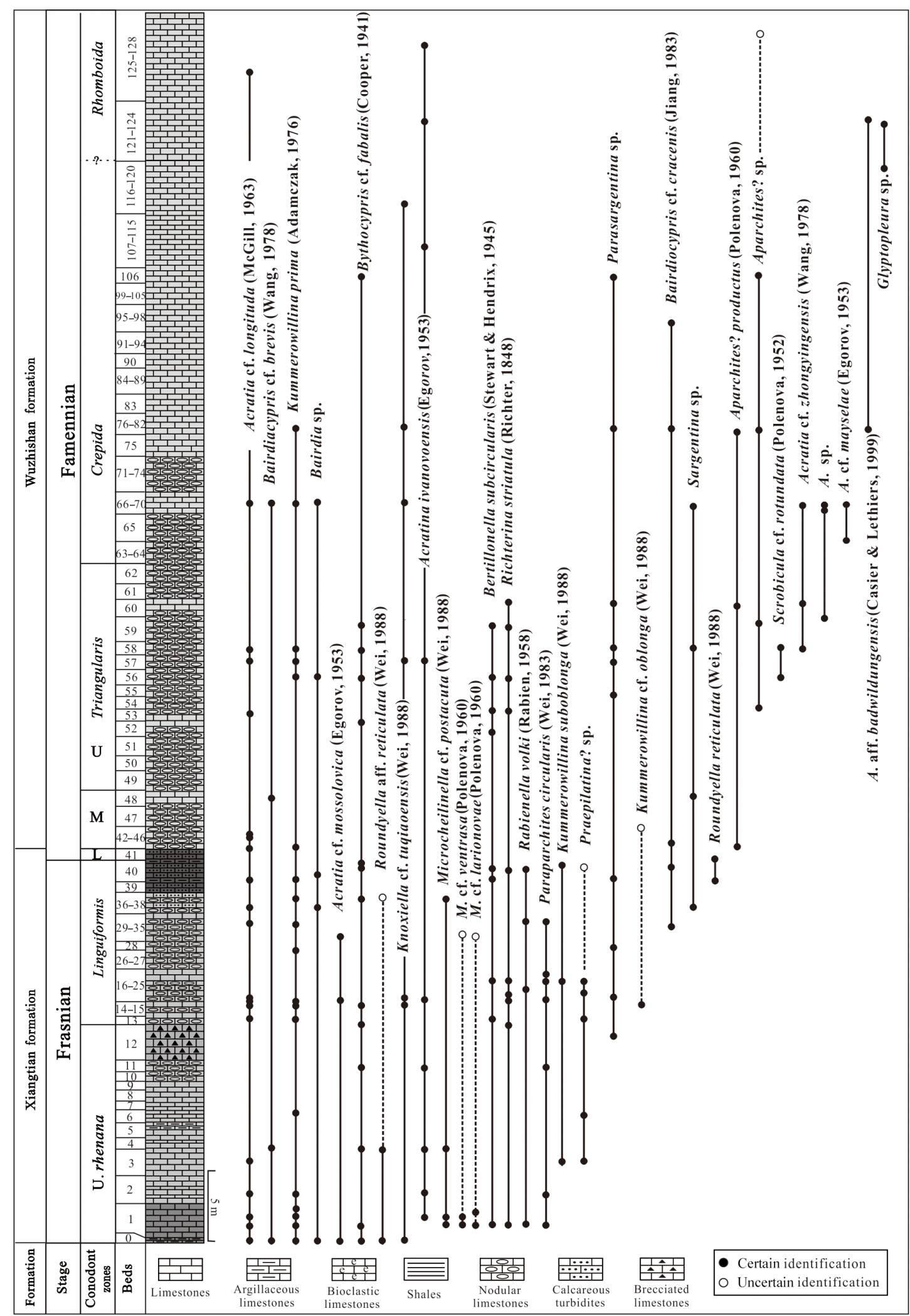

Figure 2. Distribution of ostracods in the Late Devonian in the Yangdi section, South China (log and conodont zones from Huang and Gong, 2016). 


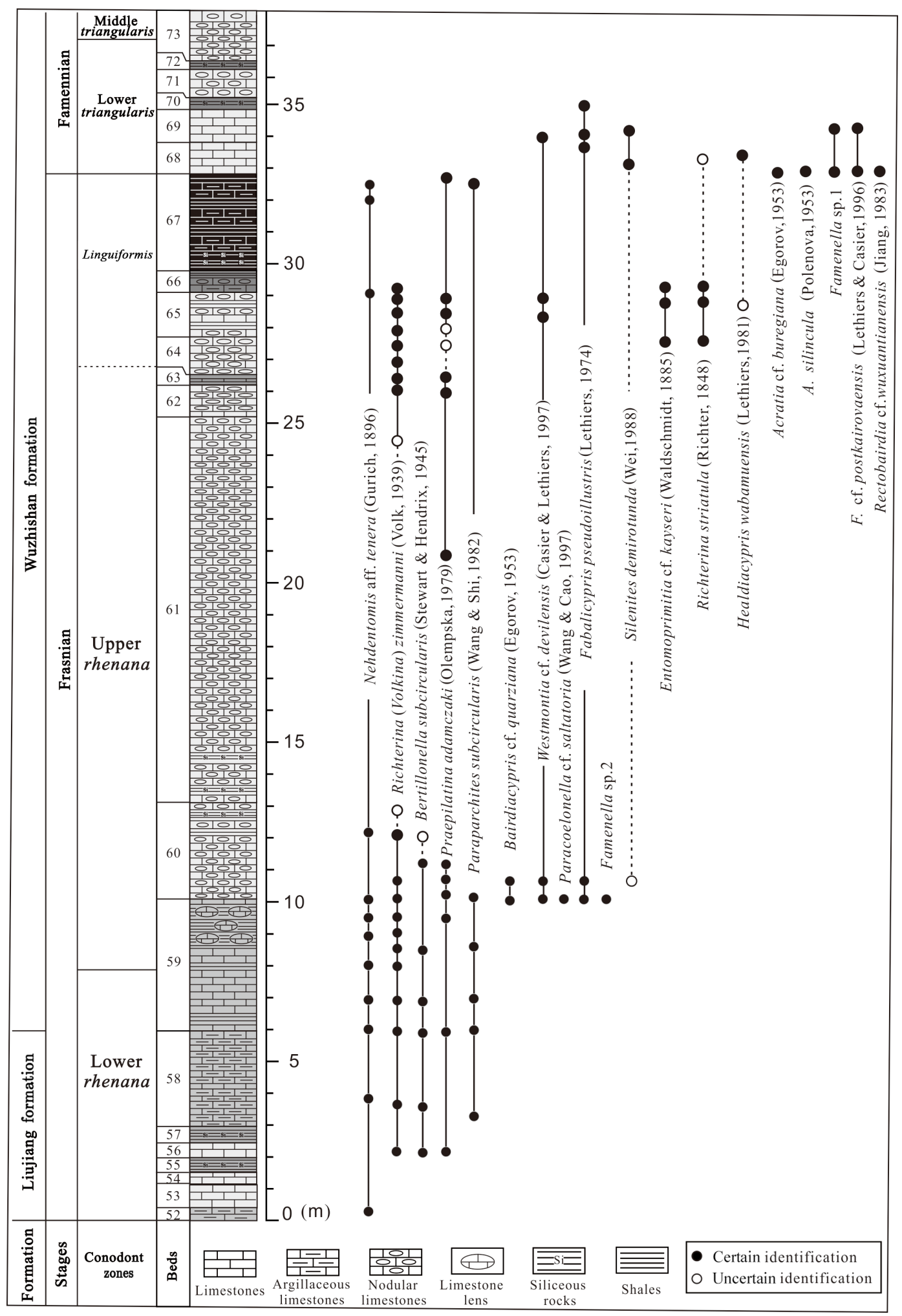

Figure 3. Distribution of ostracods in the Late Devonian in the Nandong section, South China (log and conodont zones from Huang, 2015). 


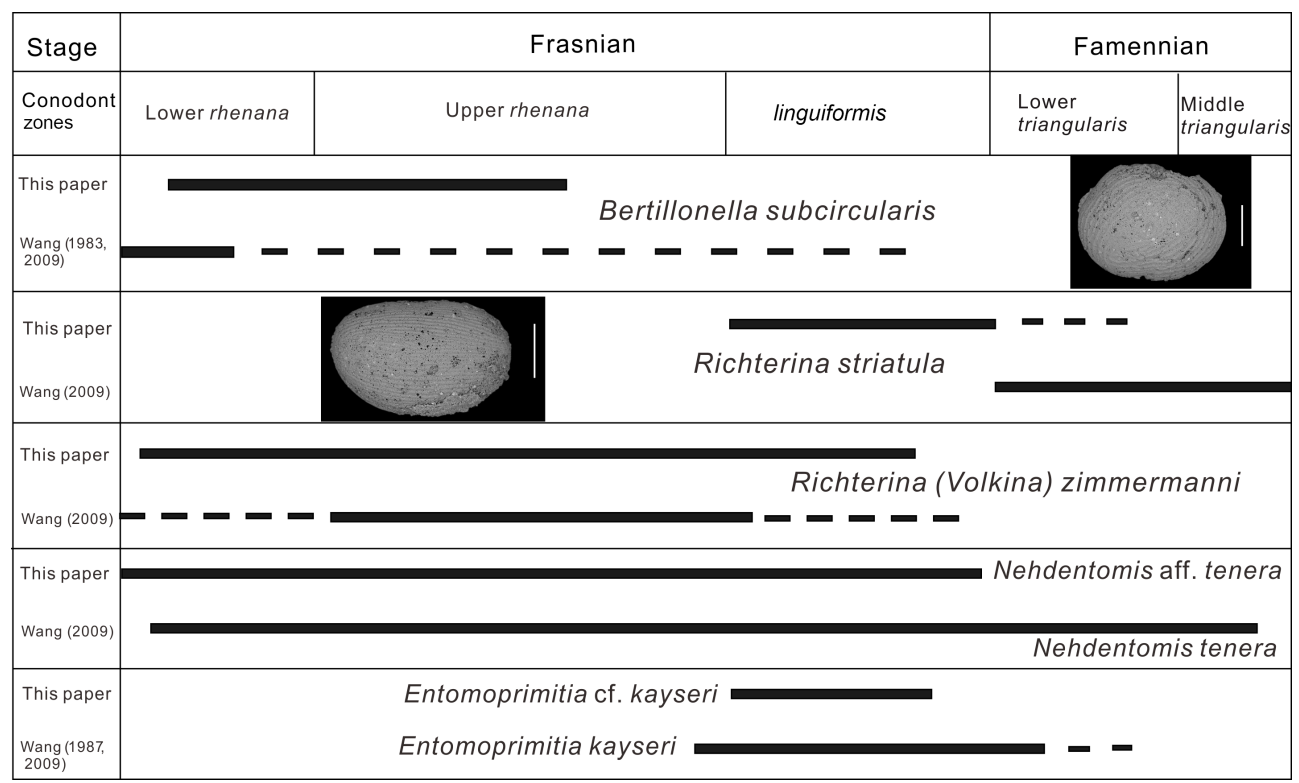

Figure 4. Comparison of the distribution of entomozoacean ostracod found in the Nandong section (conodont zones from Huang, 2015; scale bars represent $200 \mu \mathrm{m})$.

\section{Material and methods}

Three periods of fieldwork, from 2012 to 2015, have been carried out in South China to sample the Yangdi and Nandong sections. In total, 131 and 81 samples were collected respectively from the two studied sections (Yangdi and Nandong). The so-called "hot-acetolysis" method was used to extract ostracods from limestones (Lethiers and CrasquinSoleau, 1988; Crasquin-Soleau et al., 2005). For siliceous rocks, the ostracods were extracted after dilute hydrofluoric acid (HF) (2 to $5 \%$ ) processing, the same method used to extract radiolarians from cherts (Pessagno Jr. and Newport, 1972). About 1000 and 1500 specimens were thus obtained from the Yangdi (including single valves and carapaces) and Nandong (mostly single valves) sections, respectively. In total, 48 species belonging to 28 genera were recognized: 31 species belonging to 19 genera in the Yangdi section and 19 species belonging to 15 genera in the Nandong section (Figs. 2, 3). All specimens figured in this paper are deposited in the palaeontological collections of the Museum of the China University of Geosciences (Wuhan, People's Republic of China) numbered from YD15001 to YD15034 (Yangdi section) and ND15001 to ND15022 (Nandong section).

\section{Entomozoacean from the Nandong section}

Although the pelagic entomozoacean ostracod faunas show high abundance in the Nandong section, they cannot be ascribed to the entomozoacean zonation summarized by Wang (2009) for South China. Indeed, the diversity is low (five species belonging to four genera). Bertillonella subcir- cularis Stewart \& Hendrix, 1945 (Plate 3, fig. 16) is one of the characteristic species of the suberecta-subcircularis entomozoacean Zone in South China (Wang, 1984). According to the newly established conodont zonation (Huang, 2015) in the Nandong section, suberecta-subcircularis Zone may be equivalent to the lower rhenana Zone and middle part of upper rhenana Zone (Fig. 4). Richterina striatula (Richter, 1848) (Plate 4, figs. 1, 2) was widespread in the Famennian of Europe, North Africa, and South China (Kummerow, 1939; Rabien, 1954; Olempska, 1979, 2002; Casier, 1985, 1986; Wang, 1984, 2009). However, the first appearance of this species seems to be earlier in the Nandong section than that in previous reports and should be in the late Frasnian linguiformis Zone (Fig. 4). Richterina (Volkina) zimmermanni (Volk, 1939) (Plate 4, figs. 3, 4) was reported from the Frasnian of Europe, North Africa, and South China (Rabien, 1954; Olempska, 2002; Casier, 1982; Wang, 1983, 1984, 2009). Nehdentomis aff. tenera (Gürich, 1896) (Plate 4, fig. 6) is similar to Nehdentomis tenera (Gürich, 1896), which was discovered in the Frasnian-Famennian transitional deposits from South China (Wang, 2009). In particular, these two species range in rhenana-linguiformis zones based on the results of conodonts in the Nandong section (Fig. 4). Entomoprimitia cf. kayseri (Waldschmidt, 1885) (Plate 3, fig. 15) is close to Entomoprimitia kayseri (Waldschmidt, 1885), which is one of the most characteristic species in the Frasnian-Famennian in Europe and South China (e.g. Waldschmidt, 1885; Walliser et al., 1989; Casier and Lethiers, 1998; Olempska, 2002; Wang, 1987, 2009). Entomoprimitia cf. kayseri just appeared in the late Frasnian linguiformis Zone in the Nandong section (Fig. 4). 


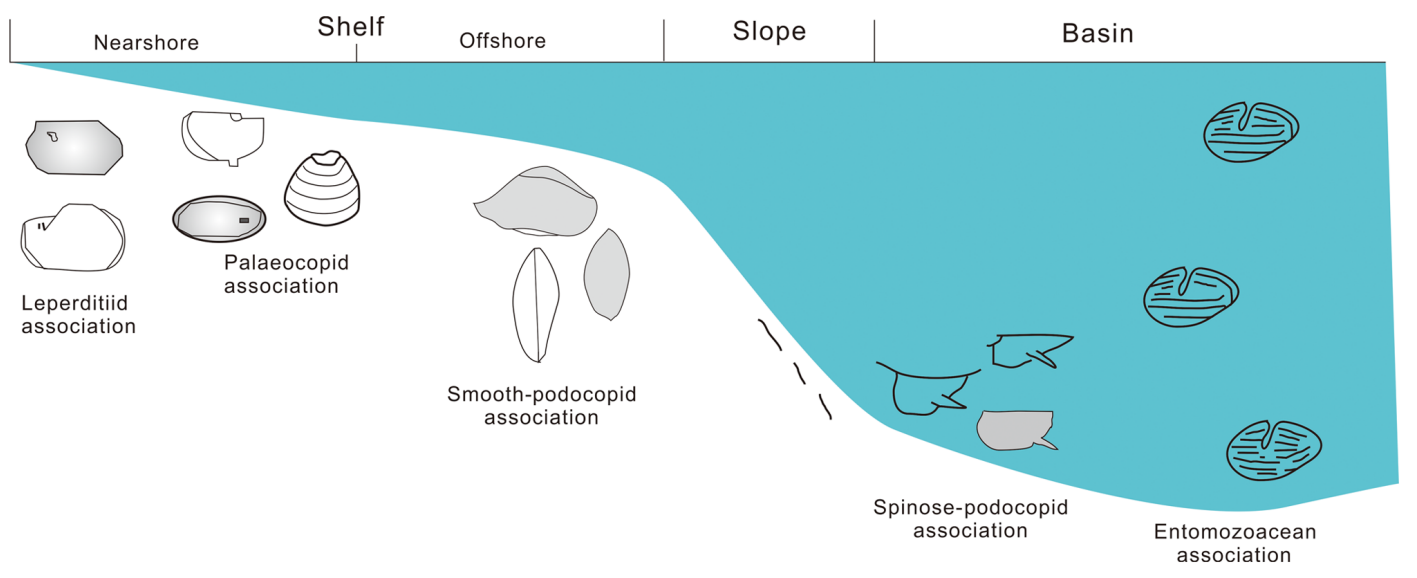

Figure 5. The ecological position of Late Palaeozoic ostracod associations from South China (Wang, 1988).

\section{Palaeoenvironmental analysis}

Five ostracod associations were recognized in the Palaeozoic strata of the South China by Wang (1988) i.e. the leperditiid, palaeocopid, smooth-podocopid, spinose-podocopid, and entomozoacean associations, which represent the palaeoenvironments from the nearshore to deep basins (Fig. 5). Following Wang (1988), the smooth-podocopid association was generally characterized by a rich bairdiacean fauna with smooth carapaces and is indicative of offshore environments. The entomozoacean association characterized by entomozoid and/or cyprinoid ostracods is indicative of deep-water basin environments.

The ostracod faunas from the Yangdi section are dominated by podocopids (about $63 \%$ of total number of species) and palaeocopids (about $22 \%$ of species). Myodocopids and platycopids are rare, just 9 and $6 \%$ of species, respectively. Therefore, the ostracod assemblage belongs to the smooth-podocopid association (Fig. 5), which consists of Bairdioidea (e.g. Bairdia McCoy, 1844; Acratia Delo, 1930; Bairdiacypris Bradfield, 1935; Fabalicypris Cooper, 1946; and Bythocypris Brady, 1880), Bairdiocypridoidea (such as Bairdiocypris Kegel, 1932 and Praepilatina Polenova, 1970) and Healdioidea (i.e. Kummerowillina Adamczak, 1978). Previous studies have indicated that entomozoaceans (pelagic "fingerprint" ostracods) prefer living in low-energy deeper waters (Bandel and Beker, 1975; Casier et al., 1995; Becker and Bless, 1987; Wang, 1988; Lethiers and Casier, 1995; Olempska, 2002; Casier, 2004, 2008). Generally, the entomozoacean association (equivalent to the Myodocopid Mega-Assemblage of Casier, 2004, 2008) reflects an environment of deep-water basin (Wang, 1988). However, some studies from South China showed that the water depth could be shallower when there is a mixed assemblage of benthic and pelagic ostracods (Wang, 1984, 1987, 1988). The smooth-podocopid association was accompanied by some entomozoids (three species belonging to three genera) in the Yangdi section. Among these are Bertillonella subcircularis Stewart \& Hendrix, 1945 and Richterina striatula (Richter, 1848) up to Bed 60; this implies environments from a carbonate platform to a slope. Further up, environments becomes shallower as attested by the disappearance of entomozoids and by a carbonate platform environment. It may be a response to the regression that was reported in the early Famennian in South China (Zong et al., 2015). Geochemistry, sedimentology, and other faunal evidence (e.g. conodonts) suggest a slope environment in the Yangdi section (Ji, 1989; Ma and Bai, 2002; Chen et al., 2013; Huang and Gong, 2016). However, none of the spinose podocopids (indicative of deep- and cold-water environments; Blumenstengel, 1965, 1979; Kozur, 1972; Bandel and Becker, 1975; Lethiers and Crasquin, 1987; Wang, 1988; Casier, 2004; some authors also considered spinose-podocopid ostracod assemblages as indicative for low-energy environments, which might not be particularly deep or cold; Becker, 2000; Groos-Uffenorde et al., 2000) were found together with the smooth-podocopid association in the Yangdi section. This means a deposition in a shallower environment than that of the slope. So we deduce that the Xiangtian and Wuzhishan formations in the Yangdi section were deposited on an external carbonate platformslope setting during a regression.

The ostracod faunas from the Nandong section are dominated by podocopids (65\% of total number of species) and myodocopids (25\% of total number of species). Palaeocopids and platycopids are rare, with each having just $5 \%$ of the total number of species. The ostracod assemblage is represented by smooth podocopids (i.e. Bairdioidea and Bairdiocypridoidea), which is similar to the ostracod faunas in the Yangdi section. However, thin-shelled entomozoaceans show a significant preponderance (more than $65 \%$ of total number of specimens) in the Nandong section. Moreover, most ostracods species are represented by relatively small 
carapaces $(<1 \mathrm{~mm})$, thin valves, and simple hinge structures, which may be a result of specialization in a low-energy and anoxic deep-water environment (Wang, 1988). Therefore, the bathymetry was deeper during the deposition of the Liujiang and Wuzhishan formations in the Nandong section than during the contemporaneous deposition in the Yangdi section. The ecological assemblages of ostracods in the Nandong section indicated a basin environment (Fig. 5).

\section{Systematic palaeontology}

The taxonomic classifications of Becker (2002) and Liebau (2005) are used in the paper. Abbreviations: CA, cardinal angles; ACA, anterior cardinal angle; PCA, posterior cardinal angle; $\mathrm{AB}$, anterior border; $\mathrm{PB}$, posterior border; $\mathrm{DB}$, dorsal border; ADB, anterodorsal border; PDB, posterodorsal border; $\mathrm{VB}$, ventral border; $\mathrm{AVB}$, anteroventral border; PVB, posteroventral border; $L$, maximum length; $H$, maximum height; $W$, maximum width.

Family Aparchitidae Jones, 1901

Genus Aparchites Jones, 1889

Aparchites? productus Polenova, 1960

(Plate 1, fig. 1)

1960 Aparchites productus Polenova: 8-9, pl. 1, fig. 2.

Material: Two carapaces and two valves.

Description: Equivalve carapace. DB straight and long; $\mathrm{CA}$ obtuse. $\mathrm{AB}$ rounded with a large radius of curvature and a maximum convexity located between first third of $H$ and mid- $H$; VB regularly curved; PB with a relative small radius of curvature and a maximum convexity located below mid- $H$. Surface smooth.

Dimensions: $\quad L=0.76-0.80 \mathrm{~mm}, \quad H=0.61-0.65 \mathrm{~mm}$, $W=0.47-0.51 \mathrm{~mm}$.

Occurrence: Late Devonian, Guangxi (Xiangtian and Wuzhishan formations of Yangdi section), South China.

Remarks: In lateral outline, the specimens resemble Aparchites productus Polenova, 1960 from the Middle Devonian of the Russian Platform (Polenova, 1960). The specimens figured by Polenova (1960, Plate 1, figs. 2a, b), as well as our specimens, do not posses the adventral structure characteristic of the genus. Therefore, our species is assigned to Aparchies with doubt.

Aparchites? sp.

(Plate 1, fig. 2)
Material: Two carapaces and two valves.

Description: $\mathrm{DB}$ straight to slightly curved; $\mathrm{AB}$ and PB rounded; VB regularly concave; left valve slightly overlaps the right along the free margins. Surface smooth.

Dimensions: $\quad L=0.36-0.42 \mathrm{~mm}, \quad H=0.30-0.37 \mathrm{~mm}$, $W=0.24-0.27 \mathrm{~mm}$.

Occurrence: Late Devonian, Guangxi (Wuzhishan Formation of Yangdi section), South China.

Remarks: In outline, the specimens resemble Aparchites circularis Wei, 1983 from Early Devonian of Sichuan, South China (Wei et al., 1983), but poor preservation makes further identification impossible.

Family Uncertain

Genus Parasargentina Zheng, 1982

Parasargentina sp.

(Plate 1, fig. 3)

Material: Two carapaces and four valves.

Description: Round ovoid carapace, DB straight to slightly arched; $\mathrm{AB}$ and $\mathrm{PB}$ rounded; $\mathrm{VB}$ regularly concave; left valve slightly overlaps the right along the free margins. Surface smooth.

Dimensions: $\quad L=0.51-0.56 \mathrm{~mm}, \quad H=0.36-0.40 \mathrm{~mm}$, $W=0.24-0.27 \mathrm{~mm}$.

Occurrence: Late Devonian, Guangxi (Xiangtian and Wuzhishan formations of Yangdi section), South China.

Remarks: In lateral outline, the specimens could be attributed to the genus Parasargentina Zheng, 1982, for their nearly straight dorsal margin and rounded $\mathrm{AB}$, but poor preservation forbids further assignation.

Family Scrobiculidae Posner, 1951

Genus Scrobicula Posner, 1951

Scrobicula cf. rotundata Polenova, 1952

(Plate 1, fig. 4)

Material: Three carapaces and two valves.

Description: DB slightly curved; $A B$ rounded with a large radius of curvature and a maximum convexity located a little below mid- $H$; VB nearly straight on left valve and regularly convex on right one; $\mathrm{PB}$ with a relative small radius of curvature and a maximum convexity located at mid- $H$. Left valve overlaps slightly the right one with a maximum at 


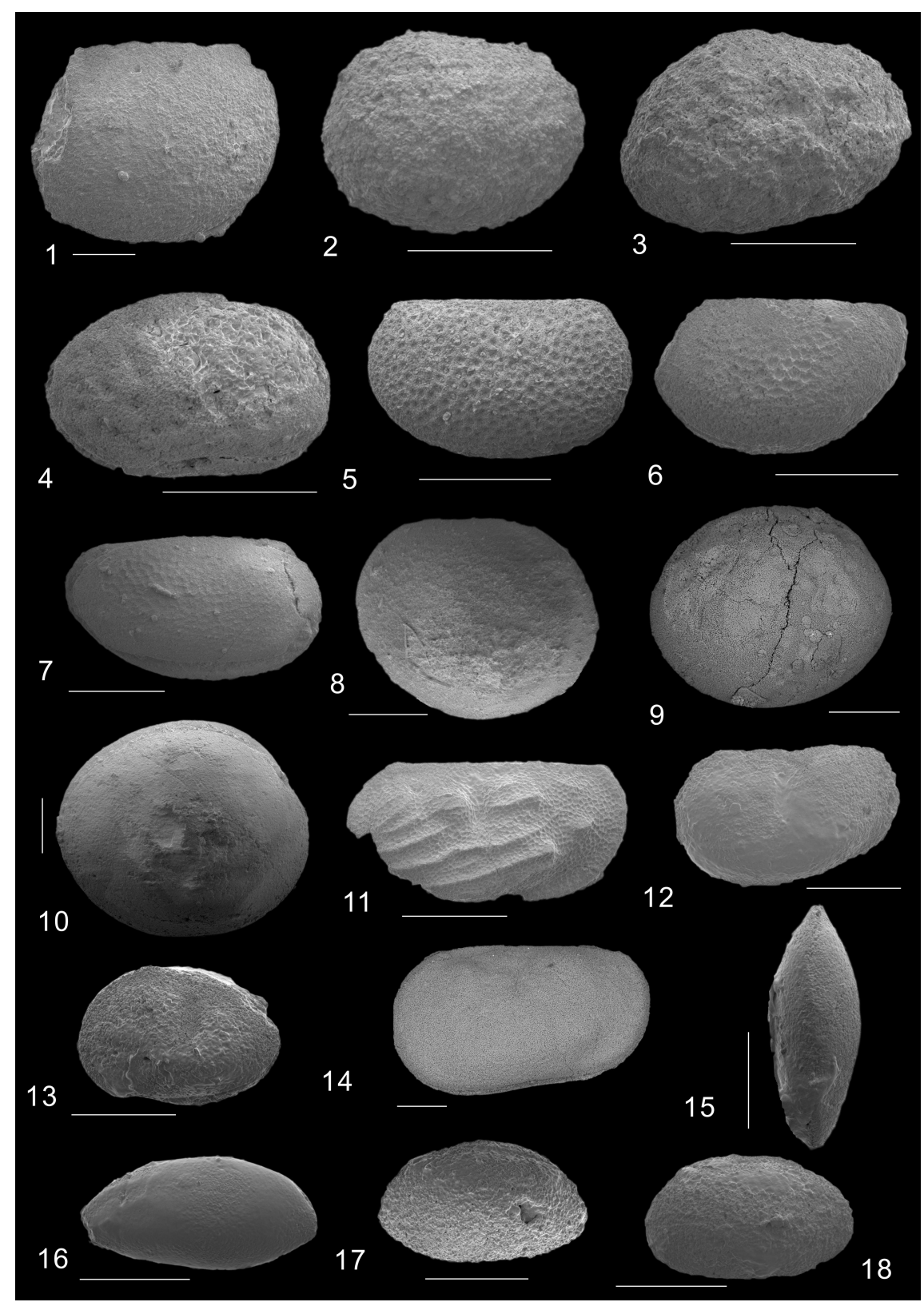

Plate 1. (1) Aparchites? productus Polenova, 1960. Right lateral view of complete carapace, YD15001, Frasnian-Famennian, Yangdi section (Bed 60). (2) Aparchites? sp. Left lateral view of complete carapace, YD15002, Famennian, Yangdi section (Bed 79). (3) Parasargentina sp. Right lateral view of complete carapace, YD15003, Frasnian-Famennian, Yangdi section (Bed 79). (4) Scrobicula cf. rotundata Polenova, 1952. Right lateral view of complete carapace, YD15004, Famennian, Yangdi section (Bed 58). (5) Roundyella reticulata Wei, 1988. Right lateral view of complete carapace, YD15005, Frasnian, Yangdi section (Bed 39). (6, 7) Roundyella aff. reticulata Wei, 1988. (6) Left lateral view of complete carapace, YD15006. (7) Right lateral view of complete carapace, YD15007; Frasnian, Yangdi section (Bed 40). (8) Paraparchites circularis (Wei, 1983). Right valve, YD15008, Frasnian, Yangdi section (Bed 1). (9, 10) Paraparchites subcircularis (Wang and Shi, 1982). (9) Right lateral view of complete carapace, ND15001. (10) Right lateral view of complete carapace, ND15002; Frasnian, Nandong section (Bed 60). (11) Glyptopleura sp. Right valve, YD15009, Famennian, Yangdi section (Bed 116). (12) Knoxiella cf. tuqiaoensis Wei, 1988. Left lateral view of complete carapace, YD15010, Frasnian-Famennian, Yangdi section (Bed 68). (13) Sargentina sp. Left lateral view of complete carapace, YD15011, Frasnian-Famennian, Yangdi section (Bed 58). (14) Westmontia cf. devilensis Casier \& Lethiers, 1997. Left lateral view of complete carapace, ND15003, Frasnian-Famennian, Nandong section (Bed 60). (15, 16) Acratia cf. longituda (McGill, 1963). (15) Dorsal view of complete carapace, YD15012. (16) Right lateral view of complete carapace, YD15013; Frasnian-Famennian, Yangdi section (Bed 41). (17, 18) Acratina ivanovoensis Egorov, 1953. (17) Right lateral view of complete carapace, YD15014. (18) Right lateral view of complete carapace, YD15015; Frasnian-Famennian, Yangdi section (Bed 123). Scale bars represent $200 \mu \mathrm{m}$. 
VB. Surface reticulated.

Dimensions: $\quad L=0.32-0.40 \mathrm{~mm}, \quad H=0.19-0.26 \mathrm{~mm}$, $W=0.20-0.26 \mathrm{~mm}$.

Occurrence: Late Devonian, Guangxi (Wuzhishan Formation of Yangdi section), South China.

Remarks: In lateral outline, the specimens are close to Scrobicula rotundata Polenova, 1952 from the Middle Devonian of the Russian Platform (Polenova, 1952), but differs by the smaller radius of curvature of the PB.

Genus Roundyella Bradfield, 1935

Roundyella reticulata Wei, 1988

(Plate 1, fig. 5)

1988 Roundyella reticulata Wei: 284, pl. 95, fig. 14.

Material: Five carapaces and six valves.

Description: Small equivalve carapace with subrectangular outline in lateral view. DB straight and long; ACA obtuse and bigger than $\mathrm{PCA}$. AB rounded with a large radius of curvature and a maximum convexity located a little below mid- $H$; VB regularly curved; PB with a relative small radius of curvature and a maximum convexity located at mid- $H$. Surface finely reticulated.

Dimensions: $\quad L=0.40-0.42 \mathrm{~mm}, \quad H=0.22-0.24 \mathrm{~mm}$, $W=0.15-0.16 \mathrm{~mm}$.

Occurrence: Middle Devonian of Longmen Mts., Sichuan, South China, and Late Devonian of Yangdi section, Guangxi, South China.

Roundyella aff. reticulata Wei, 1988

(Plate 1, figs. 6, 7)

Material: Four carapaces and six valves.

Description: Small equivalve carapace with subrectangular outline in lateral view. DB straight and long; ACA obtuse and bigger than PCA. AB rounded with a large radius of curvature and a maximum convexity located below mid- $H$; VB regularly curved; $\mathrm{PB}$ with a relative small radius of curvature and a maximum convexity located at lower third of $H$. Surface finely reticulated.

Dimensions: $\quad L=0.42-0.45 \mathrm{~mm}, \quad H=0.24-0.26 \mathrm{~mm}$, $W=0.16-0.18 \mathrm{~mm}$.

Occurrence: Late Devonian, Guangxi (Wuzhishan Formation of Yangdi section), South China.
Remarks: In lateral outline, the specimens resemble Roundyella reticulata Wei, 1988 from the Middle Devonian of Sichuan, South China (Wei, 1988), but differ by the small radius of curvature of the $\mathrm{PB}$.

Family Paraparchitidae Scott, 1959

Genus Paraparchites Ulrich \& Bassler, 1906

Paraparchites circularis (Wei, 1983)

(Plate 1, fig. 8)

1983 Aparchites circularis Wei; Wei et al.: 46, pl. 11, figs. 7-9.

1988 Antiparaparchites circularis (Wei); Wei: pl. 102, figs. 2-3.

Material: Three valves.

Description: Subrounded carapace. DB slightly curved; both $\mathrm{AB}$ and $\mathrm{PB}$ rounded with a large radius of curvature and a maximum convexity located at mid- $H$; VB regularly curved. Surface smooth.

Dimensions: $L=0.41-0.55 \mathrm{~mm}, H=0.42-0.53 \mathrm{~mm}$.

Occurrence: Late Devonian, Guangxi (Xiangtian and Wuzhishan formations of Yangdi section), South China.

Remarks: The present specimens are assigned to Paraparchites circularis (Wei et al., 1983) from the Early Devonian of Sichuan, South China. Wei (1988) changed the generic attribution, certainly due to the lack of adventral structure and referred the species to Antiparaparchites Coryell \& Rogatz, 1932. This genus is considered as a junior synonym of Paraparchites since the revision of Paraparchitoidea by Sohn $(1971,1972)$.

Paraparchites subcircularis (Wang \& Shi, 1982)

(Plate 1, figs. 9, 10)

1982 Antiparaparchites subcircularis Wang \& Shi: 103, pl. 3, figs. 11-13.

1988 Antiparaparchites subcircularis Wang \& Shi; Wei: pl. 102, fig. 6.

Material: Six carapaces and two valves.

Description: Carapace rounded. DB regularly convex; both $\mathrm{AB}$ and $\mathrm{PB}$ rounded with a large radius of curvature and a maximum convexity located at mid- $H$; VB regularly curved. Left valve overlaps the right one with maxima at DB and $\mathrm{AB}$, surface smooth.

Dimensions: $\quad L=0.75-0.81 \mathrm{~mm}, \quad H=0.74-0.80 \mathrm{~mm}$, $W=0.35-0.41 \mathrm{~mm}$. 
Occurrence: Middle Devonian of Guangxi, South China; Late Devonian of Guangxi (Liujiang and Wuzhishan formations of Nandong section), South China.

Remarks: Antiparaparchites Coryell \& Rogatz, 1932 is considered as a junior synonym of Paraparchites since the revision of Paraparchitoidea by Sohn $(1971,1972)$.

Family Glyptopleuridae Girty, 1910

Genus Glyptopleura Girty, 1910

\section{Glyptopleura sp.}

(Plate 1, fig. 11)

Material: Three valves.

Description: DB straight and long; CA obtuse and ACA larger than $\mathrm{PCA}$. Both $\mathrm{AB}$ and $\mathrm{PB}$ rounded with large radius of curvature and maximum convexity located at mid- $H$; VB regularly curved. Valve ornamented by longitudinal narrow ridges. Surface finely reticulate.

Dimensions: $L=0.68-0.72 \mathrm{~mm}, H=0.32-0.36 \mathrm{~mm}$.

Occurrence: Late Devonian, Guangxi (Wuzhishan Formation of Yangdi section), South China.

Remarks: In lateral outline, the specimens resemble Glyptopleura venosa (Ulrich, 1891) from the Late Devonian to the Early Carboniferous of the Illinois, USA (Ulrich, 1891), but broken valves forbid further assignation.

Family Geisinidae Sohn, 1961

Genus Knoxiella Egorov, 1950

Knoxiella cf. tuqiaoensis Wei, 1988

(Plate 1, fig. 12)

Material: Four carapaces.

Description: $\mathrm{DB}$ long and straight; $\mathrm{CA}$ obtuse; $\mathrm{AB}$ with a relatively large radius of curvature, and with a maximum curvature located at mid- $H$; VB regularly rounded with a maximum curvature located at posterior part of VB; PB rounded with a large radius of curvature and a maximum located at mid- $H$. A short and deep subcentral sulcus almost reaches the dorsal border.

Dimensions: $\quad L=0.43-0.50 \mathrm{~mm}, \quad H=0.30-0.35 \mathrm{~mm}$, $W=0.29-0.32$.

Occurrence: Late Devonian, Guangxi (Xiangtian and Wuzhishan formations of Yangdi section), South China.
Remarks: The specimens resemble Knoxiella tuqiaoensis Wei, 1988 from the Middle Devonian of Longmen Mts., Sichuan, South China (Wei, 1988) in outline, but poor preservation of the surface ornamentation forbids further assignation.

Genus Sargentina Coryell \& Johnson, 1939

\section{Sargentina sp.}

(Plate 1, fig. 13)

Material: Two carapaces and three valves.

Description: $\mathrm{DB}$ regularly convex; $\mathrm{AB}$ with relatively large radius of curvature with maximum located at mid- $H$; PB with small radius of curvature with maximum located a little below mid- $H$; VB slightly concave. Overlap of right valve on left one with a maximum at VB. A short subcentral sulcus located a little below DB. Surface smooth.

Dimensions: $\quad L=0.41-0.48 \mathrm{~mm}, \quad H=0.28-0.35 \mathrm{~mm}$, $W=0.26-0.32 \mathrm{~mm}$.

Occurrence: Middle Devonian of Yunnan, South China; Late Devonian of Guangxi (Xiangtian and Wuzhishan formations of Yangdi section), South China.

Remarks: In outline, the specimens are close to Sargentina arcuata (Egorov, 1950) sensu Wei et al., 1983 from the Early Devonian of Sichuan, South China (Wei et al., 1983). But $S$. arcuata is more elongate and has a larger radius of curvature at $\mathrm{PB}$. Our specimens may belong to a new species. The poor preservation could not allow a precise determination.

\section{Family Uncertain \\ Genus Westmontia Loranger, 1963}

Westmontia cf. devilensis Casier \& Lethiers, 1997

(Plate 1, fig. 14)

Material: Two carapaces and two valves.

Description: $\mathrm{DB}$ long and straight; $\mathrm{CA}$ obtuse; $\mathrm{AB}$ flattened with a relatively large radius of curvature and with a maximum located a little below mid- $H$; PB flattened with a large radius of curvature with maximum located at mid- $H$; VB straight to slightly curve. $S_{2}$ developed and nearly reach to DB. Right valve slightly overlaps the left one with a maximum at VB.

Dimensions: $\quad L=0.85-1.05 \mathrm{~mm}, \quad H=0.48-0.65 \mathrm{~mm}$, $W=0.28-0.36 \mathrm{~mm}$.

Occurrence: Late Devonian, Guangxi (Wuzhishan Formation of Nandong section), South China. 
Remarks: The specimens resemble Westmontia devilensis Casier \& Lethiers, 1997 from the Frasnian-Famennian (Late Devonian) of Nevada, USA (Casier and Lethiers, 1997), in outline, but differ by more obtuse CA.

Family Acratiidae Gründel, 1962

Genus Acratia Delo, 1930

Acratia cf. longituda (McGill, 1963)

(Plate 1, figs. 15, 16)

Material: Seven carapaces.

Description: $\mathrm{DB}$ slightly convex; $\mathrm{AB}$ with a relatively large radius of curvature and with a maximum located a little below mid- $H$; PB with a small radius of curvature and with a maximum located at mid- $H$; VB regularly curved with a maximum convexity located at between first third of $L$ and mid- $L$. Overlap of left valve on right one. Surface smooth.

Dimensions: $\quad L=0.42-0.51 \mathrm{~mm}, \quad H=0.21-0.25 \mathrm{~mm}$, $W=0.10-0.12 \mathrm{~mm}$.

Occurrence: Late Devonian, Guangxi (Xiangtian and Wuzhishan formations of Yangdi section), South China.

Remarks: In outline, our specimens are closed to Acratia longituda (McGill, 1963) from the Middle and Late Devonian of Alberta, Canada (McGill, 1963), and Chaohu, Anhui, China (Chen and Bao, 1990). But Acratia longituda (McGill, $1963)$ is more elongate.

\section{Acratia cf. mossolovica Egorov, 1953}

(Plate 2, fig. 1)

Material: Three carapaces.

Description: $\mathrm{DB}$ nearly straight; $\mathrm{AB}$ and $\mathrm{PB}$ with a relatively small radius of curvature and with a maximum located at mid- $H$; VB slightly curved to straight. Overlap of left valve on right one with a maximum at DB. Surface smooth.

Dimensions: $\quad L=0.92-1.01 \mathrm{~mm}, \quad H=0.38-0.45 \mathrm{~mm}$, $W=0.40-0.47 \mathrm{~mm}$.

Occurrence: Late Devonian, Guangxi (Xiangtian Formation of Yangdi section), South China.

Remarks: In outline, our specimens resemble Acratia mossolovica Egorov, 1953 from the Late Devonian of the Russian Platform (Egorov, 1953). But A. mossolovica is more elongate and has a larger radius of curvature at $\mathrm{AB}$ and PB. Our specimens may belong to a new species.

Acratia cf. mayselae Egorov, 1953
(Plate 2, fig. 2)

Material: Three carapaces.

Description: Carapace diamond-shaped in lateral outline; DB regularly arched; $\mathrm{ADB}$ and PDB arched; $\mathrm{AB}$ and PB with small radius of curvature and with maxima located at mid- $H$; VB regularly concave. Left valve slightly overlaps the right with a maximum at VB. Surface smooth.

Dimensions: $\quad L=0.58-0.68 \mathrm{~mm}, \quad H=0.38-0.45 \mathrm{~mm}$, $W=0.34-0.41 \mathrm{~mm}$.

Occurrence: Late Devonian, Guangxi (Wuzhishan Formation of Yangdi section), South China.

Remarks: In lateral outline, these specimens resemble Acratia mayselae Egorov, 1953 from the Late Devonian of the Russian Platform (Egorov, 1953). They differ by a more tapered AB.

\section{Acratia cf. zhongyingensis Wang, 1978}

(Plate 2, fig. 3)

Material: Two carapaces and three valves.

Description: $\mathrm{DB}$ regularly convex; $\mathrm{AB}$ with a large radius of curvature and with a maximum located between first third of $H$ and mid- $H$; PB with a relative small radius of curvature and with a maximum located at lower third of $H$; VB nearly straight. Left valve slightly overlaps the right one along the free margins with a maximum at DB and VB. Surface smooth.

Dimensions: $\quad L=0.41-0.50 \mathrm{~mm}, \quad H=0.21-0.28 \mathrm{~mm}$, $W=0.17-0.24 \mathrm{~mm}$.

Occurrence: Late Devonian, Guangxi (Wuzhishan Formation of Yangdi section), South China.

Remarks: In lateral outline, the specimens resemble Acratia zhongyingensis Wang, 1978 from the Late Permian of Guizhou, China (Wang, 1978). It differs by being more elongate.

\section{Acratia cf. buregiana Egorov, 1953}

(Plate 2, fig. 4)

Material: Five carapaces.

Description: $\mathrm{DB}$ slightly convex; $\mathrm{AB}$ with a relatively small radius of curvature and with a maximum located at lower third of $H$; PB with a large radius of curvature and with a maximum located at mid- $H$; VB slightly concave. Overlap of left valve on right one with a maximum at DB. Surface smooth. 


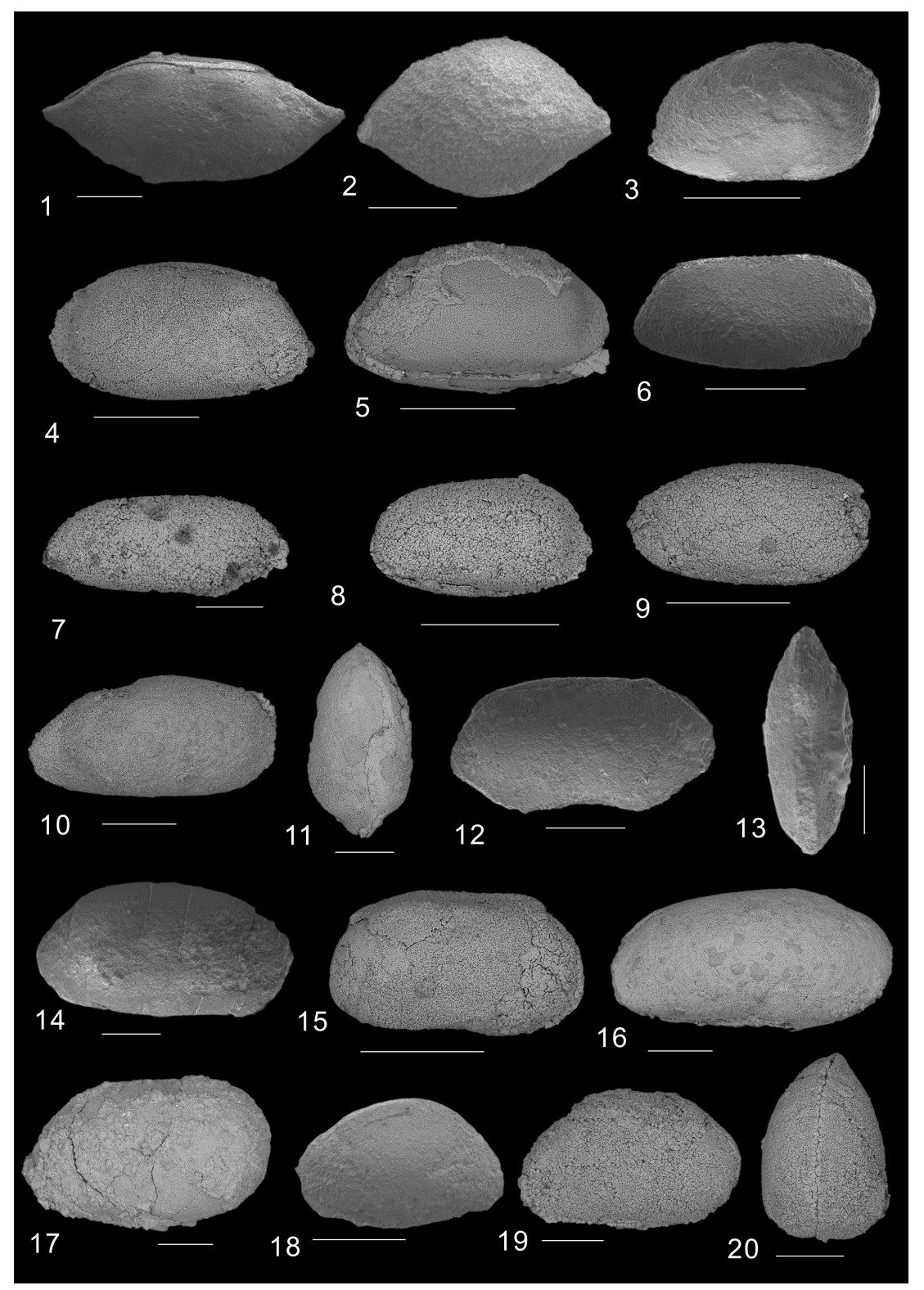

Plate 2. (1) Acratia cf. mossolovica Egorov, 1953. Right lateral view of complete carapace, YD15016, Frasnian, Yangdi section (Bed 0). (2) Acratia cf. mayselae Egorov, 1953. Right lateral view of complete carapace, YD15017, Famennian, Yangdi section (Bed 68). (3) Acratia cf. zhongyingensis Wang, 1978. Right lateral view of complete carapace, YD15018, Famennian, Yangdi section (Bed 58). (4) Acratia cf. buregiana Egorov, 1953. Right lateral view of complete carapace, ND15004, Famennian, Nandong section (Bed 68). (5) Acratia cf. silincula Polenova, 1953. Right lateral view of complete carapace, ND15005, Famennian, Nandong section (Bed 68). (6) Acratia aff. badwildungensis Casier \& Lethiers, 1999. Right lateral view of complete carapace, YD15019, Famennian, Yangdi section (Bed 79). (7) Acratia sp. Right lateral view of complete carapace, YD15020, Famennian, Yangdi section (Bed 68). (8) Famenella cf. postkairovaensis Lethiers \& Casier, 1996. Right lateral view of complete carapace, ND15006, Famennian, Nandong section (Bed 68). (9) Famenella sp. 1. Right lateral view of complete carapace, ND15007, Famennian, Nandong section (Bed 68). (10, 11) Famenella sp. 2. Right lateral view and dorsal view of complete carapace, respectively, ND15008, Frasnian, Nandong section (Bed 59). (12, 13) Bairdia sp. Right lateral view and dorsal view of complete carapace, respectively, YD15021, Frasnian-Famennian, Yangdi section (Bed 0). (14) Bairdiacypris cf. brevis (Wang, 1978) sensu Wei et al., 1983. Right lateral view of complete carapace, YD15022, Frasnian-Famennian, Yangdi section (Bed 0). (15) Bairdiacypris cf. quarziana (Egorov, 1953) sensu Casier \& Lethiers, 1998. Right lateral view of complete carapace, ND15009, Frasnian, Nandong section (Bed 60). (16) Fabalicypris pseudoillustris Lethiers, 1974. Right lateral view of complete carapace, ND15010, Frasnian-Famennian, Nandong section (Bed 60). (17) Rectobairdia cf. wuxuantianensis Jiang in Wei et al., 1983. Right lateral view of complete carapace, ND15011, Famennian, Nandong section (Bed 68). (18) Bythocypris cf. fabalis Cooper, 1941. Right lateral view of complete carapace, YD15023, Frasnian-Famennian, Yangdi section (Bed 3). (19, 20) Healdiacypris wabamuensis Lethiers, 1981. (19) Right lateral view of complete carapace, ND15012. (20) Dorsal view of complete carapace, ND15013; Famennian, Nandong section (Bed 68). Scale bars represent 200 $\mu$ m. 
Dimensions: $\quad L=0.58-0.65 \mathrm{~mm}, \quad H=0.32-0.38 \mathrm{~mm}$, $W=0.20-0.24 \mathrm{~mm}$.

Occurrence: Late Devonian, Guangxi (Wuzhishan Formation of Nandong section), South China.

Remarks: The specimens are close to Acratia buregiana Egorov, 1953 from the Late Devonian of the Russian Platform (Egorov, 1953) in outline, but they differ by a sharper $\mathrm{ADB}$ and a rounder $\mathrm{AB}$.

Acratia cf. silincula Polenova, 1953

(Plate 2, fig. 5)

Material: Four carapaces.

Description: $D B$ slightly curve; $A B$ with relatively a large radius of curvature and with a maximum located at mid- $H$; PB with a small radius of curvature and with a maximum located at lower third of $H$; VB nearly straight. Slight overlap of left valve on right one; maximum at VB. Surface smooth.

Dimensions: $\quad L=0.48-0.60 \mathrm{~mm}, \quad H=0.28-0.38 \mathrm{~mm}$, $W=0.25-0.35 \mathrm{~mm}$.

Occurrence: Late Devonian, Guangxi (Wuzhishan Formation of Nandong section), South China.

Remarks: The specimens resemble Acratia silincula Polenova, 1953 from Frasnian-Famennian (Late Devonian) of the Russian Platform (Polenova, 1953) in outline, but differ by a flattened $\mathrm{AB}$.

Acratia aff. badwildungensis Casier \& Lethiers, 1999

(Plate 2, fig. 6)

Material: Five carapaces.

Description: $\mathrm{DB}$ straight; $\mathrm{AB}$ with relatively a large radius of curvature and with a maximum located at mid- $H$; $\mathrm{PB}$ with a small radius of curvature and with a maximum located at lower third of $H$; VB regularly curved. Left valve slightly overlaps the right one with a maximum at DB. Surface smooth.

Dimensions: $\quad L=0.48-0.60 \mathrm{~mm}, \quad H=0.21-0.31 \mathrm{~mm}$, $W=0.19-0.28 \mathrm{~mm}$.

Occurrence: Late Devonian, Guangxi (Wuzhishan Formation of Yangdi section), South China.

Remarks: In lateral outline, the specimens strongly resemble Acratia badwildungensis Casier \& Lethiers, 1999 from Frasnian-Famennian (Late Devonian) of the Schmidt quarry, Germany (Casier et al., 1999). They differ by a more elongate carapace and an $\mathrm{AB}$ with a larger radius of curvature.

Acratia sp.

(Plate 2, fig. 7)

Material: Three carapaces and two valves.

Description: DB straight, almost equal and parallel to VB; AB and PB taping. The left valve slightly overlaps the right one. Surface smooth.

Dimensions: $\quad L=0.52-0.67 \mathrm{~mm}, \quad H=0.23-0.33 \mathrm{~mm}$, $W=0.20-0.25 \mathrm{~mm}$.

Occurrence: Late Devonian of western Junggar, NW China, and Guangxi (Wuzhishan Formation of Yangdi section), South China.

Remarks: In outline, the specimens resemble Acratia tanaica Egorov, 1953 from the Late Devonian of the Russian Platform (Egorov, 1953), but broken valves forbid further assignation.

Genus Acratina Egorov, 1953

Acratina ivanovoensis Egorov, 1953

(Plate 1, figs. 17, 18)

1953 Acratina ivanovoensis Egorov: 45, pl. 20, fig. $5 \mathrm{a}-\mathrm{c}$.

2017 Acratina ivanovoensis Egorov; Song et al.: 266, fig. 8B.

Material: Four carapaces and three valves.

Description: DB nearly straight, $\mathrm{ADB}$ and PDB straight; $\mathrm{AB}$ with a small radius of curvature and with a maximum located below mid- $H$; PB with a relative large radius of curvature and with a maximum located at lower third of $H$; VB nearly straight. Left valve slightly overlaps the right one along the free margins with maxima at DB and VB. Surface smooth.

Dimensions: $\quad L=0.41-0.50 \mathrm{~mm}, \quad H=0.21-0.28 \mathrm{~mm}$, $W=0.17-0.24 \mathrm{~mm}$.

Occurrence: Frasnian-Famennian (Late Devonian) of the Russian Platform, western Junggar, NW China, and Yangdi section, Guangxi, South China.

Genus Famenella Polenova, 1953

Famenella cf. postkairovaensis Lethiers \& Casier, 1996

(Plate 2, fig. 8) 
Material: Three carapaces and two valves.

Description: DB straight to slightly convex; $A B$ with a relatively large radius of curvature and with a maximum located below mid- $H$; PB with a small radius of curvature and with a maximum located at mid- $H$; VB straight to slightly curved. Left valve overlaps the right one with a maximum at VB. Surface smooth.

Dimensions: $\quad L=0.32-0.40 \mathrm{~mm}, \quad H=0.18-0.23 \mathrm{~mm}$, $W=0.14-0.20 \mathrm{~mm}$.

Occurrence: Late Devonian, Guangxi (Wuzhishan Formation of Nandong section), South China.

Remarks: In outline, the specimens resemble Famenella postkairovaensis Lethiers \& Casier, 1996 from the Late Devonian of Coumiac (France) (Lethiers and Casier, 1996), but differ by bigger radius of curvature of $\mathrm{PB}$ and $\mathrm{AB}$.

\section{Famenella sp. 1}

(Plate 2, fig. 9)

Material: Four carapaces and two valves.

Description: $\mathrm{DB}$ slightly convex; $\mathrm{AB}$ with a relatively large radius of curvature and with a maximum located at mid- $H$; PB with a small radius of curvature and with a maximum located at mid- $H$; VB straight to slightly curved. Left valve overlaps the right one with a maximum at VB. Surface smooth.

Dimensions: $\quad L=0.38-0.45 \mathrm{~mm}, \quad H=0.20-0.24 \mathrm{~mm}$, $W=0.17-0.21 \mathrm{~mm}$.

Occurrence: Late Devonian, Guangxi (Wuzhishan Formation of Nandong section), South China.

Remarks: These specimens are assigned to the genus Famenella Polenova, 1953 based on their outline, but poor preservation makes impossible further assignation.

\section{Famenella sp. 2}

(Plate 2, figs. 10, 11)

Material: Two carapaces and one valve.

Description: $\mathrm{DB}$ slightly convex; $\mathrm{AB}$ with a large radius of curvature and with a maximum located at mid- $H$; VB nearly straight; PB with a relative small radius of curvature and with a maximum located at the lower third of $H$; left valve slightly overlaps the right one. Surface smooth.

Dimensions: $\quad L=0.71-0.78 \mathrm{~mm}, \quad H=0.35-0.41 \mathrm{~mm}$, $W=0.40-0.45 \mathrm{~mm}$.
Occurrence: Late Devonian, Guangxi (Wuzhishan Formation of Nandong section), South China.

Remarks: These specimens are assigned to the genus Famenella Polenova, 1953, for their outline. But this one has a smaller radius of curvature of PB by comparison with other species belonging to the genus. It may be a new species; however, to date, the material is insufficient to establish a new species.

Family Bairdiidae Sars, 1887

Genus Bairdia McCoy, 1844

\section{Bairdia sp.}

(Plate 2, figs. 12, 13)

Material: Two carapaces.

Description: $\mathrm{DB}$ regularly slightly curved; $\mathrm{AB}$ and $\mathrm{PB}$ rounded and almost equal; VB slightly concave; AVB and PVB nearly straight. Left valve overlaps the right with a maximum at PB. Surface smooth.

Dimensions: $\quad L=0.61-0.65 \mathrm{~mm}, \quad H=0.32-0.35 \mathrm{~mm}$, $W=0.25-0.28 \mathrm{~mm}$.

Occurrence: Late Devonian, Guangxi (Xiangtian and Wuzhishan formations of Yangdi section), South China.

Remarks: In outline, the specimens are close to Bairdia dushanensis Shi, 1964, from the Middle and Late Devonian of Guizhou, South China (Shi, 1964). The difference is the larger radius of curvature of PB in our specimens and the maximum located higher. They may belong to a new species.

Genus Bairdiacypris Bradfield, 1935

Bairdiacypris cf. brevis (Wang, 1978) sensu Wei et al., 1983

(Plate 2, fig. 14)

Material: Four carapaces.

Description: $\mathrm{DB}$ slightly convex; $\mathrm{AB}$ with a relatively large radius of curvature and with a maximum located at mid- $H$; PB with a small radius of curvature and with a maximum located at below mid- $H$; VB straight to slightly curved. Left valve slightly overlaps the right one. Surface smooth.

Dimensions: $\quad L=0.80-0.90 \mathrm{~mm}, \quad H=0.41-0.49 \mathrm{~mm}$, $W=0.28-0.34 \mathrm{~mm}$. 
Occurrence: Late Devonian, Guangxi (Xiangtian and Wuzhishan formations of Yangdi section), South China.

Remarks: In lateral outline, the specimens resemble Bairdiacypris brevis (Wang, 1978) sensu Wei et al., 1983 from the Late Permian of Guizhou, South China (Wei et al., 1983), but they differ by less overlap at VB.

Bairdiacypris cf. quarziana (Egorov, 1953) sensu Casier \& Lethiers, 1998

(Plate 2, fig. 15)

Material: Two carapaces and three valves.

Description: $\mathrm{DB}$ straight; $\mathrm{AB}$ with a relatively large radius of curvature and with a maximum located below mid$H$; PB with a small radius of curvature with a maximum located at the lower third of $H$; VB slightly convex. Left valve overlaps the right one with a maximum at $\mathrm{DB}$ and $\mathrm{AB}$. Surface smooth.

Dimensions: $\quad L=0.41-0.50 \mathrm{~mm}, \quad H=0.26-0.33 \mathrm{~mm}$, $W=0.22-0.28 \mathrm{~mm}$.

Occurrence: Late Devonian, Guangxi (Wuzhishan Formation of Nandong section), South China.

Remarks: The specimens resemble Bairdiacypris quarziana (Egorov, 1953) sensu Casier \& Lethiers, 1998, from the Late Devonian of Nevada, USA (Casier and Lethiers, 1998), in outline, but differs by a smaller radius of curvature on $\mathrm{AB}$.

Genus Fabalicypris Cooper, 1946

Fabalicypris pseudoillustris Lethiers, 1974

(Plate 2, fig. 16)

1974 Fabalicypris pseudoillustris Lethiers: 1616, pl. 1, figs. 3, 4.

Material: Four carapaces three valves.

Description: $\mathrm{DB}$ slightly curved; $\mathrm{AB}$ and $\mathrm{PB}$ rounded and nearly equal; VB straight to slightly convex. Left valve overlaps the right one, with a maximum at VB. Surface smooth.

Dimensions: $\quad L=0.85-0.90 \mathrm{~mm}, \quad H=0.43-0.48 \mathrm{~mm}$, $W=0.32-0.35 \mathrm{~mm}$.

Occurrence: Late Devonian-Early Carboniferous of the Dinant Basin, Belgium, and Late Devonian of Guangxi (Wuzhishan Formation of Nandong section), South China.

Genus Rectobairdia Sohn, 1960

Rectobairdia cf. wuxuantianensis Jiang, 1983
(Plate 2, fig. 17)

Material: Two carapaces and three valves.

Description: $\mathrm{DB}$ nearly straight; $\mathrm{AB}$ with a large radius of curvature and with a maximum located at mid- $H$; $\mathrm{PB}$ with a relative small radius of curvature and with a maximum located at the lower third of $H$; VB slightly curved. Left valve slightly overlaps the right one with maximum at VB. Surface smooth.

Dimensions: $\quad L=0.71-0.89 \mathrm{~mm}, \quad H=0.41-0.52 \mathrm{~mm}$, $W=0.37-0.44 \mathrm{~mm}$.

Occurrence: Late Devonian, Guangxi (Wuzhishan Formation of Nandong section), South China.

Remarks: The outline of our specimens is similar to Rectobairdia wuxuantianensis Jiang, 1983 from the Middle Devonian of South China (Wei et al., 1983), but our specimens differ by larger carapaces and a smaller overlap on DB.

Family Bythocyprididae Maddocks, 1969

Genus Bythocypris Brady, 1880

Bythocypris cf. fabalis Cooper, 1941

(Plate 2, fig. 18)

Material: Two carapaces and three valves.

Description: $\mathrm{DB}$ regularly arched and $\mathrm{ADB}$ and $\mathrm{PDB}$ almost equally inclined; $\mathrm{AB}$ with a small radius of curvature and with a maximum located at lower third of $H$; PB with a relatively larger radius of curvature and with a maximum located at mid- $H$; VB slightly convex. Left valve overlaps right one with a maximum at VB. Surface smooth.

Dimensions: $\quad L=0.30-0.41 \mathrm{~mm}, \quad H=0.19-0.27 \mathrm{~mm}$, $W=0.16-0.24 \mathrm{~mm}$.

Occurrence: Late Devonian of Guangxi (Xiangtian and Wuzhishan formations of Yangdi section), South China.

Remarks: In outline the specimens resemble Bythocypris fabalis Cooper, 1941, from the Early Carboniferous of Illinois, USA (Cooper, 1941), but differ by a smaller radius of curvature at $\mathrm{PB}$.

Family Bairdiocyprididae Shaver, 1961

Genus Healdiacypris Bradfield, 1935

Healdiacypris wabamuensis Lethiers, 1981 
(Plate 2, figs. 19, 20)

1981 Healdiacypris wabamuensis Lethiers: 66, pl. 12, figs. 116-119.

Material: Eight carapaces and three valves.

Description: $\mathrm{DB}$ regularly convex; $\mathrm{AB}$ with a relatively large radius of curvature and with a maximum located at mid- $H$; PB with a small radius of curvature and with a maximum located at lower third of $H$; VB nearly straight. Left valve overlaps the right one with maxima at DB and AB. Surface smooth.

Dimensions: $\quad L=0.53-0.70 \mathrm{~mm}, \quad H=0.30-0.44 \mathrm{~mm}$, $W=0.30-0.40 \mathrm{~mm}$.

Occurrence: Late Devonian, western Canada, and Guangxi (Wuzhishan Formation of Nandong section), South China.

Genus Bairdiocypris Kegel, 1932

Bairdiocypris cf. cracenis Jiang, 1983

(Plate 3, fig. 1)

Material. Three carapaces and two valves.

Description: $\mathrm{DB}$ regularly convex; $\mathrm{AB}$ with a relatively large radius of curvature and with a maximum located a little below mid- $H$; PB with a small radius of curvature and with a maximum located at lower third of $H$; VB nearly straight. Left valve strongly overlaps the right one with maxima at DB and ADB. Surface smooth.

Dimensions: $\quad L=0.92-1.10 \mathrm{~mm}, \quad H=0.57-0.61 \mathrm{~mm}$, $W=0.40-0.45 \mathrm{~mm}$.

Occurrence: Late Devonian, Guangxi (Xiangtian and Wuzhishan formations of Yangdi section), South China.

Remarks: The specimens strongly resemble Bairdiocypris cracenis Jiang, 1983 from the Middle Devonian of Yunnan, South China (Wei et al., 1983) in outline. However, the broken carapaces forbid further attribution.

Genus Praepilatina Polenova, 1970

Praepilatina adamczaki Olempska, 1979

(Plate 3, fig. 2)

1979 Praepilatina adamczaki Olempska: 115, pl. 22, fig. 5 .

1997 Praepilatina adamczaki Olempska; Olempska: 313, fig. 10G, H.

2017 Praepilatina adamczaki Olempska: Song et al.: 268 , fig. $8 \mathrm{~J}$.
Material: Four carapaces and two valves.

Description: $\mathrm{DB}$ strongly convex, $\mathrm{ADB}$ and $\mathrm{PDB}$ almost symmetrically inclined; $\mathrm{AB}$ and $\mathrm{PB}$ widely rounded; VB straight to slightly concave. Left valve overlaps right one all around carapace with maxima at VB and AB. Surface smooth.

Dimensions: $\quad L=0.46-0.58 \mathrm{~mm}, \quad H=0.32-0.43 \mathrm{~mm}$, $W=0.21-0.33 \mathrm{~mm}$.

Occurrence: Late Devonian of Holy Cross Mts., Poland, western Junggar, Xinjiang, NW China, and Guangxi (Liujiang and Wuzhishan formations of Nandong section), South China.

\section{Praepilatina? sp. \\ (Plate 3, fig. 3)}

Material: Three valves.

Description: Carapace rounded in lateral outline. DB strongly curved; $\mathrm{PB}$ slight rounder than $\mathrm{AB}$; VB regularly curved. Left valve slightly overlaps the right one along the free margins with maximum at VB. Surface smooth.

Dimensions: $L=0.50-0.60 \mathrm{~mm}, H=0.46-0.55 \mathrm{~mm}$.

Occurrence: Late Devonian, Guangxi (Xiangtian and Wuzhishan formations of Yangdi section), South China.

Remarks: Based on the rounded outline our specimens may be assigned to the genus Praepilatina Polenova, 1970. The specimens in outline resemble Praepilatina subcirculata Wang \& Ma, 2007 from the Late Devonian in Xikuangshan, Hunan, China (Wang and Ma, 2007), but they differ by a more curved PVB. Our specimens perhaps belong to a new species, but at present the material is insufficient to establish it.

Genus Silenites Coryell \& Booth, 1933

Silenites demirotunda Wei, 1988

(Plate 3, fig. 13)

1988 Silenites demirotunda Wei: 301, pl. 109, figs. 11-13.

Material: Three carapaces and two valves.

Description: Carapace arched. DB regularly curved; both $\mathrm{AB}$ and $\mathrm{PB}$ rounded with a small radius of curvature and a maximum convexity located at lower third of $H$. VB straight. Slight overlap of left valve on right one with a maximum at DB. Surface smooth. 


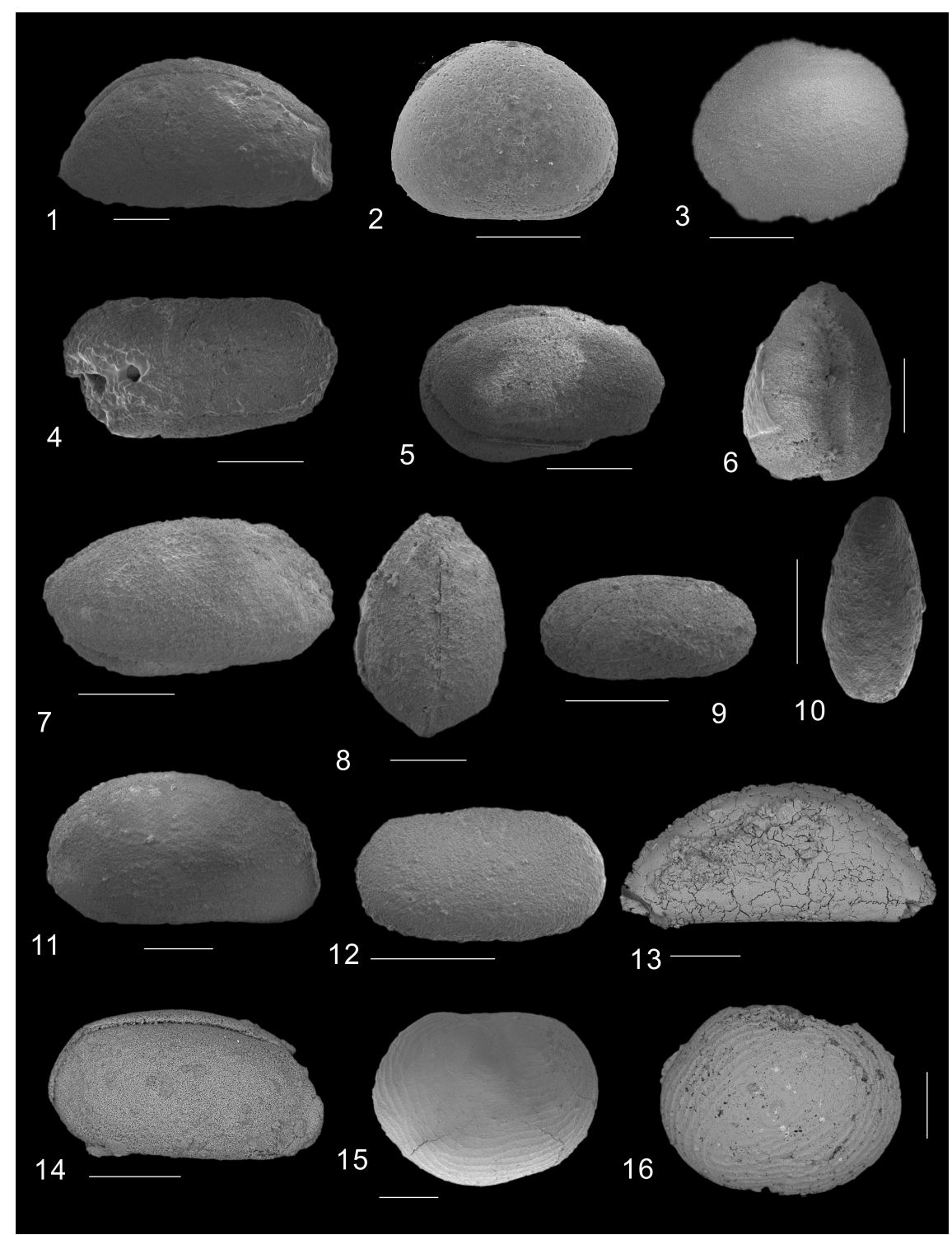

Plate 3. (1) Bairdiocypris cf. cracenis Jiang, 1983. Right lateral view of complete carapace, YD15024, Frasnian-Famennian, Yangdi section (Bed 98). (2) Praepilatina adamczaki Olempska, 1979. Right lateral view of complete carapace, ND15014, Frasnian-Famennian, Nandong section (Bed 68). (3) Praepilatina? sp. Right valve, YD15025, Frasnian, Yangdi section (Bed 21). (4) Microcheilinella cf. postacuta Wei, 1988. Right lateral view of complete carapace, YD15026, Frasnian, Yangdi section (Bed 1). (5, 6) Microcheilinella cf. ventrasa Polenova, 1960. Right lateral view and dorsal view of complete carapace, respectively, YD15027, Frasnian, Yangdi section (Bed 1). (7, 8) Microcheilinella cf. larionovae Polenova, 1960. Right lateral view and dorsal view of complete carapace, respectively, YD15028, Frasnian, Yangdi section (Bed 1). (9, 10) Kummerowillina prima (Adamczak, 1976). (9) Right lateral view of complete carapace, YD15029; (10) Dorsal view of complete carapace, YD15030; Frasnian-Famennian, Yangdi section (Bed 68). (11) Kummerowillina cf. oblonga (Wei, 1988). Right lateral view of complete carapace, YD15031, Frasnian, Yangdi section (Bed 15). (12) Kummerowillina suboblonga (Wei, 1988). Right lateral view of complete carapace, YD15032, Frasnian, Yangdi section (Bed 15). (13) Silenites demirotunda Wei, 1988. Right lateral view of complete carapace, ND15015, Frasnian-Famennian, Nandong section (Bed 68). (14) Paracoelonella cf. saltatoria Wang \& Cao, 1997. Left lateral view of complete carapace, ND15016, Frasnian, Nandong section (Bed 60). (15) Entomoprimitia cf. kayseri (Waldschmidt, 1885). Right lateral view of complete carapace, ND15022, Frasnian, Nandong section (Bed 66). (16) Bertillonella subcircularis Stewart \& Hendrix, 1945. Right lateral view of complete carapace, ND15017, Frasnian-Famennian, Yangdi section (Bed 54); Frasnian, Nandong section (Bed 59). Scale bars represent $200 \mu \mathrm{m}$. 
Dimensions: $\quad L=0.71-0.80 \mathrm{~mm}, \quad H=0.33-0.41 \mathrm{~mm}$, $W=0.25-0.32 \mathrm{~mm}$.

Occurrence: Late Devonian of Sichuan and Guangxi (Wuzhishan Formation of Nandong section), South China.

Family Microcheilinellidae Gramm, 1975

Genus Microcheilinella Geis, 1933

Microcheilinella cf. postacuta Wei, 1988

(Plate 3, fig. 4)

Material: Three carapaces.

Description: DB straight; VB slightly curved on left valve and straight on right one; both $\mathrm{AB}$ and $\mathrm{PB}$ rounded, the former smaller. Strong overlap of left valve on right one all around the carapace with maxima at PVB and PB. Surface smooth.

Dimensions: $\quad L=0.63-0.70 \mathrm{~mm}, \quad H=0.21-0.25 \mathrm{~mm}$, $W=0.24-0.28 \mathrm{~mm}$.

Occurrence: Late Devonian, Guangxi (Xiangtian Formation of Yangdi section), South China.

Remarks: In lateral outline, the specimens strongly resemble Microcheilinella postacuta Wei, 1988, from the Early Devonian of Sichuan, South China (Wei, 1988). It differs by its stronger overlap at PVB.

Microcheilinella $\mathrm{cf}$. ventrasa Polenova, 1960

(Plate 3, figs. 5, 6)

Material: Two carapaces and five valves.

Description: $D B$ regularly arched; $A B$ with a small radius of curvature and with a maximum located below mid- $H$; PB with a relative large radius of curvature and with a maximum located at mid- $H$; VB regularly curved on left valve and nearly straight on right one. Left valve strongly overlaps the right one, with a minimum at AB. Surface smooth.

Dimensions: $\quad L=0.67-0.72 \mathrm{~mm}, \quad H=0.45-0.48 \mathrm{~mm}$, $W=0.48-0.51 \mathrm{~mm}$.

Occurrence: Late Devonian, Guangxi (Xiangtian Formation of Yangdi section), South China.

Remarks: The specimens resemble Microcheilinella ventrasa Polenova, 1960, from the Middle Devonian of the Russian Platform (Polenova, 1960) in outline. It differs by its more elongate lateral outline and smaller overlap at AVB.

Microcheilinella cf. larionovae Polenova, 1960
(Plate 3, figs. 7, 8)

Material: Two carapaces and two valves.

Description: DB slightly arched; both $\mathrm{AB}$ and $\mathrm{PB}$ rounded and quite equivalent; VB slightly curved. Left valve overlaps the right one with maxima at VB and PVB. Surface smooth.

Dimensions: $\quad L=0.60-0.65 \mathrm{~mm}, \quad H=0.34-0.38 \mathrm{~mm}$, $W=0.40-0.43 \mathrm{~mm}$.

Occurrence: Late Devonian, Guangxi (Xiangtian Formation of Yangdi section), South China.

Remarks: The specimens resemble in outline $\mathrm{Mi}$ crocheilinella larionovae Polenova, 1960 from the Middle Devonian of the Russian Platform (Polenova, 1960). It differs by absence of pit ornamentation on the valves.

Family Healdiidae Harlton, 1933

Genus Kummerowillina Adamczak, 1978

Kummerowillina prima (Adamczak, 1976)

(Plate 3, figs. 9, 10)

1976 Kummerowia prima Adamczak: 394, pl. 30, figs. 197-199.

1978 Kummerowillina prima Adamczak: 515.

1988 Kummerowia prima Adamczak; Wei: pl. 109, fig. 5 .

Material: Five carapaces.

Description: Small and almost quadrangular carapace. Both DB and VB nearly straight; both $\mathrm{AB}$ and $\mathrm{PB}$ rounded and quite equivalent. Overlap of left valve on right valve all around the carapace with a maximum at VB. Surface smooth.

Dimensions: $\quad L=0.34-0.40 \mathrm{~mm}, \quad H=0.16-0.20 \mathrm{~mm}$, $W=0.08-0.12 \mathrm{~mm}$.

Occurrence: Middle Devonian of Poland, Early Devonian of Sichuan, South China and Late Devonian of Guangxi (Xiangtian and Wuzhishan formations of Yangdi section), South China.

Remarks: The genus of Kummerowia Adamczak, 1976 is in reality a junior synonym of Kummerowia Samoilova \& Smirnova, 1960. It has been replaced by Kummerowillina (Adamczak, 1978).

Kummerowillina cf. oblonga (Wei, 1988)

(Plate 3, fig. 11)

Material: Two carapaces and three valves. 
Description: $D B$ regularly arched; $A B$ with a small radius of curvature and with a maximum of curvature located at lower third of $H$; $\mathrm{PB}$ with a relative large radius of curvature and with a maximum located at mid- $H$; VB nearly straight to slightly convex. Left valve overlaps the right one with maxima at VB and PVB. Surface smooth.

Dimensions: $\quad L=0.75-0.82 \mathrm{~mm}, \quad H=0.37-0.43 \mathrm{~mm}$, $W=0.25-0.30 \mathrm{~mm}$.

Occurrence: Late Devonian, Guangxi (Xiangtian Formation of Yangdi section), South China.

Remarks: The specimens resemble Kummerowia $o b$ longa Wei, 1988 from the Middle Devonian of Longmen Mts., South China (Wei, 1988) in outline. It differs by its straighter VB and a smaller overlap on PB.

Kummerowllina suboblonga (Wei, 1988)

(Plate 3, fig. 12)

1988 Kummerowia suboblonga Wei: 300, pl. 109, fig. 10.

2017 Kummerowia suboblonga Wei; Song et al.: 272, fig. 9L-M

Material: Four carapaces and two valves.

Description: Small and almost quadrangular carapace. Both DB and VB straight and nearly parallel; $\mathrm{AB}$ and $\mathrm{PB}$ almost equivalent and regularly rounded. Left valve slightly overlaps the right one along the free margins. Surface smooth.

Dimensions: $\quad L=0.40-0.45 \mathrm{~mm}, \quad H=0.20-0.24 \mathrm{~mm}$, $W=0.20-0.25 \mathrm{~mm}$.

Occurrence: Early Devonian of Sichuan, South China; Late Devonian of western Junggar, NW China, and Guangxi (Xiangtian Formation of Yangdi section), South China.

Family Uncertain

Genus Paracoelonella Wang, 1983

Paracoelonella cf. saltatoria Wang \& Cao, 1997

(Plate 3, fig. 14)

Material: Two carapaces and two valves

Description: $\mathrm{DB}$ regularly convex; $\mathrm{AB}$ with a relatively large radius of curvature and with a maximum located at mid- $H$; PB with a small radius of curvature and with a maximum located at lower third of $H$; VB nearly straight. The right valve strongly overlaps the left one with a minimum at PB. Some small nodules distribute irregularly on the surface.

Dimensions: $\quad L=0.60-0.68 \mathrm{~mm}, \quad H=0.28-0.33 \mathrm{~mm}$, $W=0.24-0.27 \mathrm{~mm}$.

Occurrence: Late Devonian, Guangxi (Wuzhishan Formation of Nandong section), South China.

Remarks: The specimens close to Paracoelonella saltatoria Wang \& Cao, 1997 from the Early Devonian of Yunnan, South China (Wang and Cao, 1997) in outline. However, in our specimens the ADB is sharper and the VB is straighter.

Family Entomozoidae Přibyl, 1951

Genus Entomoprimitia Kummerow, 1939

Entomoprimitia cf. kayseri (Waldschmidt, 1885)

(Plate 3, fig. 15)

Material: One carapaces and four valves.

Description: Carapace subelliptic. $\mathrm{DB}$ straight; $\mathrm{AB}$ and PB rounded and nearly equal; VB regularly convex. Surface with 10 concentric ribs, and four to five longitudinal ribs in the middle part of the carapace; a small node is present at the end of sulcal depression. The sulcus is shallow and short.

Dimensions: $\quad L=1.00-1.20 \mathrm{~mm}, \quad H=0.96-1.08 \mathrm{~mm}$, $W=0.35 \mathrm{~mm}$.

Occurrence: Late Devonian, Guangxi (Wuzhishan formations of Nandong section), South China.

Remarks:The specimens resemble Entomoprimitia kayseri (Waldschmidt, 1885) from the Late Devonian of Germany (Waldschmidt, 1885) in outline. It differs by the absence of swelling and node before the sulcal depression.

Genus Bertillonella Stewart \& Hendrix, 1945

Bertillonella subcircularis Stewart \& Hendrix, 1945

(Plate 3, fig. 16)

1945 Bertillonella subcircularis Stewart \& Hendrix: 100, pl. 11, figs. 1, 2.

1981 Bertillonella subcircularis Stewart \& Hendrix 1945; Duffield \& Warshauer: 81, pl. 3, figs. 11, 12 .

1984 Bertillonella subcircularis Stewart \& Hendrix 1945; Wang: 30, pl. 3, fig. 6.

1987 Bertillonella subcircularis Stewart \& Hendrix 1945; Wang: 315, pl. 2, fig. 12. 


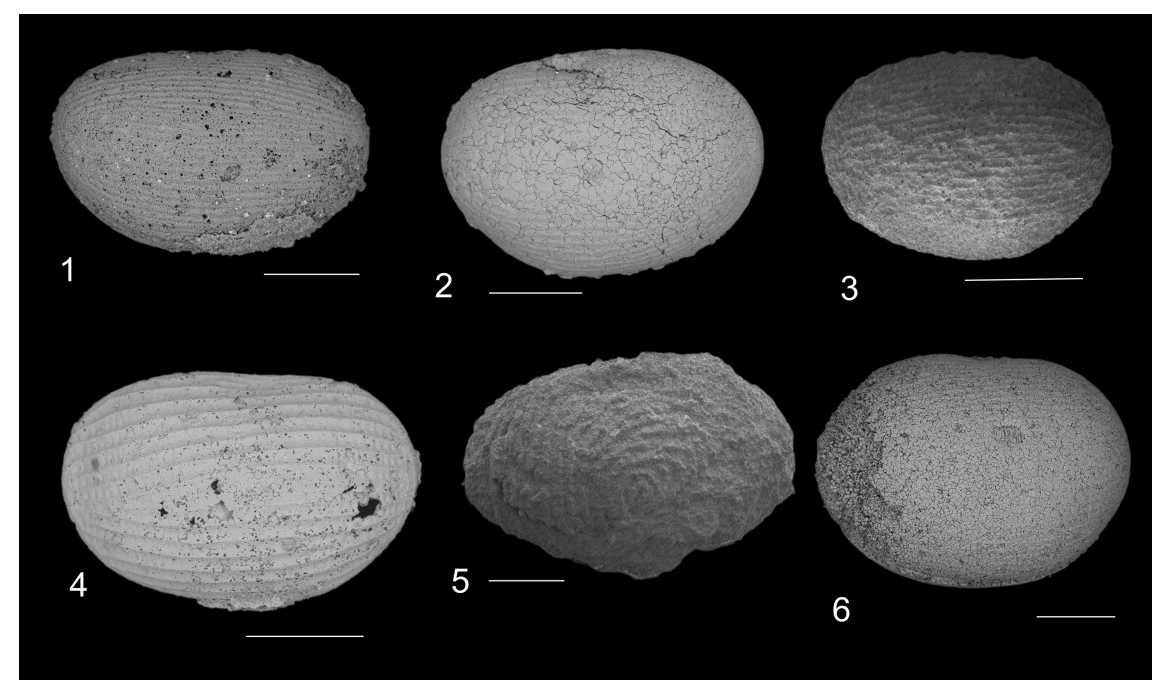

Plate 4. (1, 2) Richterina striatula (Richter, 1848). (1) Right lateral view of complete carapace, YD15033, Frasnian-Famennian, Yangdi section (Bed 1). (2) Right lateral view of complete carapace, ND15018, Frasnian, Nandong section (Bed 65). (3, 4) Richterina (Volkina) zimmermanni (Volk, 1939). (3) Right lateral view of complete carapace, ND15019. (4) Right lateral view of right valve, ND15020; Frasnian, Nandong section (Bed 60). (5) Rabienella volki (Rabien, 1958). Right valve, YD15034, Frasnian, Yangdi section (Bed 1). (6) Nehdentomis aff. tenera (Gürich, 1896). Right lateral view of complete carapace, ND15021, Frasnian, Nandong section (Bed 65). Scale bars represent $200 \mu \mathrm{m}$.

2009 Bertillonella subcircularis Stewart \& Hendrix 1945; Wang: 39, pl. 12, figs. 10, 11.

Material: Three carapaces and 12 valves.

Description: Carapace subelliptic. DB straight to slightly curved; $\mathrm{AB}$ and $\mathrm{PB}$ rounded and nearly equal; VB regularly convex. Surface with 15-20 concentric ribs; outer ribs extending parallel to margins; central ones are less-developed, arranged in circular or oval pattern.

Dimensions: $\quad L=1.00-1.30 \mathrm{~mm}, \quad H=0.96-1.10 \mathrm{~mm}$, $W=0.36-0.45 \mathrm{~mm}$.

Occurrence: Late Devonian of Ohio and Virginia, USA; Middle-Late Devonian of Guangxi (Yangdi and Nandong sections), South China.

Genus Richterina Gürich, 1896

Richterina striatula (Richter, 1848)

(Plate 4, figs. 1, 2)

1848 Cytherina striatula Richter: 64, pl. 5, fig. 56. 1913 Richterina striatula Reinh. Richter; Paeckelmann: 192, pl. 3, fig. 6 .

1939 Richterina (Richterina) striatula (Richter); Kummerow: 60, pl. 7, fig. 6.

1954 Richterina (Richterina) striatula (Reinh.Richter 1848); Rabien: 119, pl. 2, fig. 15; pl. 4, fig. 37.
1978 Richterina (Richterina) striatula (Richter); Gooday: 110, pl. 1, figs. 1-3.

1979 Richterina (Richterina) striatula (Richter, 1848); Olempska: 139, pl. 30, fig. 10.

1984 Richterina (Richterina) striatula (Richter); Wang: 53, pl. 12, fig. 3A-D.

1985 Richterina striatula (Richter); Casier: pl. 3. fig. 43.

1992 Richterina (Richterina) striatula (Richter, 1848); Olempska: fig. 2A-I, fig. 3A-D.

2009 Richterina striatula (Richter 1848); Wang: 76, pl. 26, figs. 10-12.

Material: 12 carapaces and 12 valves.

Description: Carapace oval. DB regularly convex, CA obtuse; $\mathrm{AB}$ and $\mathrm{PB}$ rounded and equal; VB regularly concave. Surface with about 25 longitudinal ribs; outer ribs extending parallel to margins; central ones are lessdeveloped, arranged in circular or oval pattern.

Dimensions: $\quad L=0.50-0.60 \mathrm{~mm}, \quad H=0.36-0.40 \mathrm{~mm}$; $W=0.25-0.28 \mathrm{~mm}$.

Occurrence: Late Devonian of Germany, Poland, France, Belgium, and Algeria; Late Devonian, Guangxi (Yangdi and Nandong section), South China.

Richterina (Volkina) zimmermanni (Volk, 1939) 
(Plate 4, figs. 3, 4)

1939 Entomis (Nehdentomis) zimmermanni Volk: 250, pl. 1, fig. 10.

1954 Richterina (Volkina) zimmermanni (Volk); Rabien: 110, pl. 2, fig. 14; pl. 4, figs. 33, 34.

1975 Richterina (Volkina) zimmermanni (Volk); Casier: pl. 3, fig. 2a-c.

1982 Richterina (Volkina) zimmermanni (Volk); Casier: pl. 2, fig. 6.

1984 Richterina (Volkina) zimmermanni (Volk); Wang: 51, pl. 12, figs. 1-3.

2002 Richterina (Volkina) zimmermanni (Volk); Olempska: 262, fig. 9C-E.

2009 Richterina (Volkina) zimmermanni (Volk); Wang: 70, pl. 25, figs. 1-3.

2011 Richterina (Volkina) zimmermanni (Volk); Nazik \& Groos-Uffenorde: 172, pl. 1, fig. 9.

Material: 15 carapaces and six valves.

Description: Carapace ovate. DB straight to slightly curved, $\mathrm{CA}$ obtuse; $\mathrm{AB}$ and $\mathrm{PB}$ rounded and nearly equal; VB regularly convex. Surface with about 15-20 longitudinal ribs; outer ribs extending parallel to margins; central ones are less-developed, arranged in oval pattern.

Dimensions: $\quad L=0.68-0.86 \mathrm{~mm}, \quad H=0.49-0.61 \mathrm{~mm}$; $W=0.30-0.48 \mathrm{~mm}$.

Occurrence: Late Devonian of Germany, Poland, France, Belgium, Algeria, Turkey, and Guangxi (Liujiang and Wuzhishan formations of Nandong section), South China.

Genus Rabienella Gründel, 1962

Rabienella volki (Rabien, 1958)

(Plate 4, fig. 5)

1958 Waldeckella volki Rabien; Rabien \& Rabitz: 173, pl. 1, fig. 2.

1987 Rabienella volki (Rabien); Wang: 311, pl. 1, figs. 4-8.

1989 Rabienella volki (Rabien); Groos-Uffenorde and Wang: pl. 2, fig. 13.

2009 Rabienella volki (Rabien); Wang: 50-51, pl. 17, figs. 4-8.

Material: Five valves.

Description: Carapace oval. $\mathrm{DB}$ regularly convex; $\mathrm{AB}$ and $\mathrm{PB}$ rounded and equal; VB regularly concave. Surface with about 15 concentric ribs; outer ribs extending parallel to margins; central ones arranged in circular or oval pattern.

Dimensions: $L=0.95-1.00 \mathrm{~mm}, H=0.54-0.57 \mathrm{~mm}$.

Occurrence: Late Devonian of Germany and Guangxi (Xiangtian Formation of Yangdi section), South China.

Genus Nehdentomis Matern, 1929

Nehdentomis aff. tenera (Gürich, 1896)

(Plate 4, fig. 6)

Material: Five carapaces and three valves.

Description: Carapace ovate. DB straightened to slightly curved; $\mathrm{AB}$ and $\mathrm{PB}$ rounded and nearly equal; VB regularly convex. Surface with longitudinal ribs; central ones are less developed.

Dimensions: $\quad L=0.73-0.88 \mathrm{~mm}, \quad H=0.55-0.65 \mathrm{~mm}$, $W=0.30-0.37 \mathrm{~mm}$.

Occurrence: Late Devonian, Guangxi (Wuzhishan Formation of Nandong section), South China.

Remarks: The specimens resemble Nehdentomis tenera (Gürich, 1896) from the Early Devonian of South China (Wang, 2009) in outline and longitudinal ribs, but differs by larger radius of curvature of $\mathrm{AB}$ and $\mathrm{PB}$, and $N$. tenera is more elongate. It may belong to a new species.

\section{Conclusions}

Forty-eight benthic and pelagic ostracod species belonging to 28 genera from the Late Devonian of the Yangdi and Nandong sections in South China are described and figured. These two sections are well documented for the sedimentology and the biostratigraphy. In total, 31 species belonging to 19 genera from the Yangdi section and 19 species belonging to 15 genera from the Nandong section are reported. The ostracod assemblage from the Nandong section can be attributed to the rhenana-linguiformis conodont zones. Richterina striatula (Richter, 1848) first appeared earlier than in previous reports and should be present in the late Frasnian linguiformis Zone. The smooth-podocopid association is accompanied by allegedly pelagic entomozoids in the Xiangtian and Wuzhishan formations exposed in the Yangdi section, and that implies an environment of carbonate platform to slope followed by a shallowing upward succession attested by the disappearance of the entomozoids. In the Nandong section, the ostracod assemblage is dominated by abundant entomozoaceans, suggesting a basin environment.

Data availability. No data sets were used in this article. 
Competing interests. The authors declare that they have no conflict of interest.

Acknowledgements. Many thanks to Ruoying Fan and Aihua Yuan both from China University of Geosciences (Wuhan) for their help in improving the manuscript. We greatfully acknowledge Cheng Huang, Ruiwen Zong, Zhihong Wang, Tao Jiang, Xinsong Zhang, Wei Zhou, and Junning Su (all from CUG Wuhan) for their joint field work. We are greatly indebted to the reviewers, Jean-Georges Casier (RINSB, Brussels, Belgium) and Claudia Dojen (Klagenfurt am Wörthersee, Austria), and Alan Lord, editor of this journal. Their suggestions and comments have improved the manuscript. Junjun Song is grateful for the financial support for a visit to France provided by the China University of Geosciences (Wuhan) and "111 Project" (grant no. B08030). This work was financially supported by the Natural Science Foundation of China (grant nos. 41290260, 41472001).

Edited by: Alan Lord

Reviewed by: two anonymous reviewers

\section{References}

Adamczak, F.: Middle Devonian Podocopida (Ostracoda) from Poland; their morphology, systematics and occurrence, Senckenbergiana lethaea, 57, 265-467, 1976.

Adamczak, F.: Nomenclatorial notes on some Devonian ostracod taxa from Poland, Senckenbergiana lethaea, 58, p. 515, 1978.

Bai, S. L., Bai, Z. Q., Ma, X. P., Wang, D. R., and Sun, Y. L.: Devonian events and biostratigraphy of South China, Peking University Press, Beijing, 1-303, 1994.

Bandel, K. and Beker, G.: Ostracoden aus paläozoischen pelagischen Kalken der Karnischen Alpen (Silurium bis Unterkarbon), Senckenbergiana lethaea, 56, 1-84, 1975.

Becker, G.: Progress in mid Palaeozoic palaeoceanographical studies from Ostracoda - from local to global importance (a review), Senckenbergiana lethaea, 80, 555-566, 2000.

Becker, G.: Contributions to Palaeozoic Ostracod Classification [POC], No. 24. Palaeozoic Ostracoda: The standard classification scheme, Neues Jahrb. Geol. P.-A., 226, 165-228, 2002.

Becker, G. and Bless, M. J. M.: Cypridinellidae (Ostracoda) aus dem Oberdevon Hessens (Unterer Kellwasser-Kalk; Lahn-DillGebiet und östlich Sauerland, Rechtrheinisches Schiefergebirge), Geologisches Jahrbuch Hessen, 115, 29-56, 1987.

Blumenstengel, H.: Zur Taxonomie und Biostratigraphie verkieselter Ostracoden aus dem Thüringer Oberdevon, Freiberger Forschungshefte C, 183, 1-127, 1965.

Blumenstengel, H.: Die Ostrakodenfauna der Wocklumeria-Stufe (Oberdevon) bei Saalfeld im Thüringer Schiefergebirge, Z. Geol. Wissenschaft., 7, 521-557, 1979.

Casier, J.-G.: Les ostracodes des schistes à aspect "Matagne" de la partie supérieure du Frasnien de l'affleurement protégé de Boussu-en-Fagne, Belgique, Bulletin de l'Institut royal des Sciences naturelles de Belgique, Sciences de la Terre, 51, 1-33, 1975 .
Casier, J.-G.: Les Ostracodes du Frasnien et de labase du Famennien de la coupe du km 30 (Saoura, Sahara algérien), Bulletin de la Société belge de Géologie, 91, 195-207, 1982.

Casier, J.-G.: Les Ostracodes de la partie supérieure de la Formation de Teferguenite (Givétien) et de la Formation de Marhouma (Givétien-Famennien) de la coupe du km 30 (Saoura, Sahara algérien), Geobios, 18, 833-855, 1985.

Casier, J.-G.: Présence d'Entomozoacea (Ostracodes) dans la partie famennienne de la coupe du Djebel Hèche (Gourara, Sahara algérien), Geobios, 19, 261-264, 1986.

Casier, J.-G.: Etude biostratigraphique et paléoécologique des Ostracodes du récif de marbre rouge du Hautmont à Vodelée (partie supérieure du Frasnien, Bassin de Dinant, Belgique), Revue de Paléobiologie, 6, 193-204, 1987.

Casier, J.-G.: Ostracods from the late Frasnian of the Neuville railway section (Dinant Synclinorium, Belgium): relation to the Kellwasser Event, B. Soc. Geol. Fr., 174, 149-157, 2003.

Casier, J.-G.: The mode of life of Devonian entomozoacean ostracods and the Myodocopid Mega-Assemblage proxy for hypoxic events, Bulletin de l'Institut royal des Sciences naturelles de Belgique, Sciences de la Terre, 74, 73-80, 2004.

Casier, J.-G. (Ed.): Guide de l'excursion: Les ostracodes du Dévonien Moyen et Supérieur du Synclinorium de Dinant, in: Résumé des Communications et Guide de l'Excursion 22ème Réunion des Ostracodologistes de Langue Française, 2-4 June, Institut royal des Sciences naturelles de Belgique, Bruxelles, 2579, 2008.

Casier, J.-G. and Lethiers, F.: Les ostracodes survivants à l'extinction en masse du Dévonien Supérieur dans la coupe du Col de Devils Gate (Nevada, U.S.A), Geobios, 30, 811-821, 1997.

Casier, J.-G. and Lethiers, F.: Les ostracodes du Frasnien terminal (Zone à linguiformis des Conodontes) de la coupe du col de Devils Gate (Nevada, USA), Bulletin de l'Institut Royal des Sciences naturelles de Belgique, Sciences de la Terre, 68, 77-95, 1998.

Casier, J.-G. and Olempska, E.: Middle Frasnian (Devonian) ostracods from the Frasnes railway section (Dinant Synclinorium, Belgium): Taxonomy, biostratigraphy, paleoecology, Bulletin de 1'Institut Royal des Sciences Naturelles de Belgique, Sciences de la Terre, 78, 51-66, 2008.

Casier, J.-G., Kasimi, R., and Préat, A.: Les Ostracode au passage Eifelien/Givetien à Glageon (Avesnois, France), Geobios, 28, 487-499, 1995.

Casier, J.-G., Lethiers, F., and Hou, H. F.: Ostracods from the Frasnian/Famennian transition beds in the Lijiaping section (Hunan, southern China), Comptes-rendus Academie des Sciences, Paris. Sciences de la terre et des planètes, 325, 433-438, 1997.

Casier, J.-G., Lethiers, F., and Baudin, F.: Ostracods, organic matter and anoxic events associated with the Frasnian-Famennian boundary in the Schmidt quarry (Germany), Geobios, 32, 869881, 1999.

Casier, J.-G., Devleeschouwer, X., Maillet, S., Petitclerc, E., and Préat, A.: Ostracodes, rock facies and magnetic susceptibility of the Givetian/Frasnian transition at Sourd D'ave (Dinant Synclinorium, Belgium), Geol. Soc. Am., Abstracts with Programs, 43, 427, 2011.

Chen, D. Q. and Bao, H.: Discovery of Ostracodes from the Upper Wutung Group of Chaohu, Anhui and its Significance, Acta 
Micropalaeontologica Sinica, 7, 123-139, 1990 (in Chinese with English abstract).

Chen, D. Z., Wang, J. G., Racki, G., Li, H., Wang, C.Y., Ma, X. P., and Whalen, M. T.: Large sulphur isotopic perturbations and oceanic changes during the Frasnian-Famennian transition of the Late Devonian, J. Geol. Soc., 170, 465-476, 2013.

Cooper, C. L.: Chester ostracodes of Illinois, Illinois Geological Survey, Report of Investigations, 77, 1-101, 1941.

Crasquin-Soleau, S., Vaslet, D., and Le Nindre, Y. M.: Ostracods as markers of the Permian/Triassic boundary in the Khuff Formation of Saudi Arabia, Palaeontology, 48, 853-868, 2005.

Dong, R. S.: Geotectonic Evolution and Devonian Palaeotectonic Framework in South China, Journal of Chengdu College of Geology, 19, 58-64, 1982 (in Chinese with English abstract).

Duffield, S. L. and Warshauer, S. M.: Upper Devonian (Frasnian) conodonts and ostracodes from the subsurface of western West Virginia, J. Paleontol., 55, 72-83, 1981.

Egorov, V. G.: Frasnian Ostracods of the Russian Platform. 1. Kloedenellida. All-Russian Petroleum Scientific Research Geological Exploration Institute (VNIGRI), 1-175, 1950 (in Russian)

Egorov, V. G.: Ostracoda from the Frasnian stage of the Russian platform. II. Bairdiidae, Hollinidae, Kirkbyidae, Vsesoyuznogo Neftyanogo Nauchno-issledovatelskojo Geologorazvedochnogo Instituta (VNIGRI), 1-133, 1953 (in Russian).

Gong, Y. M. and Li, B. H.: Devonian Frasnian/Famennian Transitional Event Deposits and Sea-level Changes, Earth ScienceJournal of China University of Geosciences, 26, 251-257, 2001 (in Chinese with English abstract).

Gong, Y. M., Wu, Y., Du, Y. S., Feng, Q. L., and Liu, B. P.: Devonian sea-level change rhythms in South China and coupling relationships among the earthspheres, Acta Geologica Sinica, 71, 370-385, 1997 (in Chinese with English abstract).

Gong, Y. M., Li, B. H., Wang, C. Y., and Wu, Y.: Orbital cyclostratigraphy of the Devonian Frasnian-Famennian transition in South China, Palaeogeogr. Palaeocl., 168, 237-248, 2001.

Gong, Y. M., Xu, R., Tang, Z. D., Si, Y. L., and Li, B. H.: Relationships between bacteria-alga proliferating and mass extinction in the Late Devonian Frasnian-Famennian transition: enlightening from carbon isotopes and molecular fossils, Science in China, Series D, 48 1656-1665, 2005 (in Chinese with English abstract).

Gooday, A. J.: The Devonian, in: A Stratigraphical Index of British Ostracoda, edited by: Bate, R. and Robinson, E., Geological Journal Special Issue 8, Seel House Press, Liverpool, 101-120, 1978.

Groos-Uffenorde, H. and Wang, S. Q.: The entomozoacean succession of South China and Germany (Ostracoda, Devonian), Cour. Forsch. Senck., 110, 61-79, 1989.

Groos-Uffenorde, H., Lethiers, F., and Blumenstengel, H.: Ostracodes and Devonian stratigraphy, Cour. Forsch. Senck., 220, 99 $111,2000$.

Gürich, G.: Das Palaeozoikum im Polnischen Mittelgebirge, Verhandlungen der Russischen Kaiserlichen Mineralogischen Gesellschaft zu S. Petersburg, 32, 1-539, 1896.

Hou, H. F., Ji, Q., and Wang, J. X.: Preliminary report on Frasnian-Famennian events in South China, Canadian Society of Petroleum Geologists Memoir, 14, 63-69, 1988.

Horne, D. J., Cohen, A., and Martens, K.: Taxonomy, morphology and biology of Quaternary and living Ostracoda, in: The Ostra- coda: Applications in Quaternary Research, edited by: Holmes, J. A. and Chivas, A. R., American Geophysical Union, Washington, D.C., 5-36, 2002.

Huang, C.: The Peculiarities and Causes of the Devonian F-F event: evidences from high-resolution conodont biostratigraphy and chemostratigraphy in South China, $\mathrm{PhD}$ theses, China University of Geosciences, 1-140, 2015 (in Chinese with English summary).

Huang, C. and Gong, Y. M.: Timing and patterns of the FrasnianFamennian event: Evidences from high-resolution conodont biostratigraphy and event stratigraphy, Palaeogeogr. Palaeocl., 448, 317-338, 2016.

Ji, Q.: On the Frasnian-Famennian mass extinction event in South China, Cour. Forsch. Senck., 117, 275-301, 1989.

Kummerow, E.: Die Ostrakoden und Phyllopoden des deutschen Unterkarbons, Abhandlungen der Preussischen Geologischen Landesanstalt, neue Folge, 194, 6-107, 1939.

Kozur, H.: Die Bedeutung triassischer Ostracoden für stratigraphische und paläoökologische Untersuchungen, Mitteilungen der Gesellschaft der Geologie und Bergbaustudenten in Österreich, 21, 632-660, 1972.

Lethiers, F.: Nouveaux Ostracodes de la limite DevonienCarbonifere de la region-type, Comptes Rendus de l'Academie des Sciences de Paris D, 279, 1613-1616, 1974.

Lethiers, F.: Ostracodes du Devonien terminal de la Formation Big Valley, Saskatchewan et Alberta, Palaeontographica, 162, 81143, 1978.

Lethiers, F.: Uppermost Devonian Ostracodes from the Western Canada systematic, biostratigraphy and palaeoecology, Geobios, 14, 1-234, 1981.

Lethiers, F. and Casier, J.-G.: The uppermost Frasnian (Upper Kellwasser) ostracodes from Coumiac (Montagne Noire, France), Revue de Micropaléontologie, 38, 65-79, 1995.

Lethiers, F. and Casier, J.-G.: Les Ostracodes survivants à l'événement F/F dans le limitotype de Coumiac (Montagne Noire, France), Annales de la Société géologique de Belgique, 117, 137-153, 1996.

Lethiers, F. and Crasquin, S.: Reconnaissance des milieux profonds de la paleotetys a l'aide des ostracodes, B. Soc. Geol. Fr., 3, 415423, 1987.

Lethiers, F. and Crasquin-Soleau, S.: Comment extraire des microfossiles à tests calcitiques de roches calcaires dures, Revue de Micropaléontologie, 31, 56-61, 1988.

Liebau, A.: A revised classification of the higher taxa of the Ostracoda (Crustacea), Hydrobiologia, 538, 115-137, 2005.

Ma, X. P.: The Frasnian-Famennian Mass Extinction and Related Sedimentological-Geochemical Events-Evidences from South China, in: Mass Extinction and Recovery - Evidences from the Palaeozoic and Triassic of South China, edited by: Rong, J. Y. and Fang, Z. J., University of Science and Technology of China Press, Hefei, 409-436, 2004 (in Chinese with English summary).

Ma, X. P. and Bai, S. L.: Biological, depositional, microspherule, and geochemical records of the Frasnian/Famennian boundary beds, South China, Palaeogeogr. Palaeocl., 181, 325-346, 2002.

Ma, X. P., Gong, Y. M., Chen, D. Z., Racki, G., Chen, X. Q., and Liao, W. H.: The Late Devonian Frasnian-Famennian Event in South China - Patterns and causes of extinctions, sea level changes, and isotope variations, Palaeogeogr. Palaeocl., 448, 224-244, 2016. 
Maillet, S., Milhau, B., Vreulx, M., Danelian, T., Monnet, C., and Nicollin, J. P.: Ecophenotypic variation of the Devonian benthic ostracod species Cavellina rhenana Krömmelbein, 1954: A paleoenvironmental proxy for the Ardenne (France-Belgium) and Rheno-Hercynian realm, Palaeogeogr. Palaeocl., 392, 324-334, 2013.

McGill, P.: Upper and Middle Devonian ostracodes from the Beaverhill Lake Formation, Alberta, Canada, B. Can. Petrol. Geol., 11, 1-26, 1963.

Nazik, A. and Groos-Uffenorde, H.: First records of Late Devonian entomozoacean ostracods in north-western Turkey, Turk. J. Earth Sci., 20, 167-178, 2011.

Olempska, E.: Middle to Upper Devonian Ostracoda from the Southern Holy Cross Mountains, Poland, Palaeontologica Polonica, 40, 57-162, 1979.

Olempska, E.: Changes in benthic ostracod assemblages across the Devonian-Carboniferous boundary in the Holy Cross Mountains, Poland, Acta Palaeontol. Pol., 42, 291-332, 1997.

Olempska, E.: The Late Devonian Upper Kellwasser Event and entomozoacean ostracods in the Holy Cross Mountains, Poland, Acta Palaeontol. Pol., 47, 247-266, 2002.

Olempska, E. and Belka, Z.: Hydrothermal vent myodocopid ostracods from the Eifelian (Middle Devonian) of southern Morocco, Geobios, 43, 519-529, 2010.

Paeckelmann, W.: Das Oberdevon des Bergischen Landes, Abhandlungen der Preussischen Geologischen Landesanstalt, Neue Folge, 70, 1-356, 1913.

Pessagno Jr., E. A. and Newport, R. L.: A technique for extracting Radiolaria from radiolarian cherts, Micropaleontology, 18, 231234, 1972.

Polenova, E. N.: Ostracodes from the upper part of the Givetian Stage of the Russian Platform, Trudy Vsesoyuznogo Neftyanogo Nauchno-issledovatelskojo Geologorazvedochnogo Instituta (VNIGRI), Novaya Seriya, 60, 65-156, 1952 (in Russian).

Polenova, E. N.: Ostracoda from Devonian deposits of the Central Devonian Field and the Middle Volga area, Trudy Vsesoyuznogo Neftyanogo Nauchno-issledovatelskojo Geologorazvedochnogo Instituta (VNIGRI), Novaya Seriya, 68, 1-157, 1953 (in Russian).

Polenova, E. N.: Devonian ostracoda of the Kuznetsk Basin and the Munusinsk trough, Trudy Vsesoyuznogo Neftyanogo Nauchnoissledovatelskojo Geologorazvedochnogo Instituta (VNIGRI), Novaya Seriya, 152, 1-139, 1960 (in Russian).

Rabien, A.: Zur Taxionomie und Chronologie der Oberdevonischen Ostracoden, Abhandlungen des Hessischen Landesamtes für Bodenforschung, 9, 1-268, 1954.

Rabien, A. and Rabitz, A.: Das Ober-Devon von Meschede. Notizblatt des Hessischen Landesamtes für Bodenforschung in Wiesbaden, 86, 159-184, 1958.

Racheboeuf, P. R., Casier, J. -G., Plusquellec, Y., Toro, M., Mendoza, D., Da Gloria Pires de Carvalho, M., Le Hérissé, A., Paris, F., Fernandez-Martinez, E., Tourneur, F., Broutin, J., Crasquin, S., and Janvier, P.: New data on the Silurian-Devonian palaeontology and biostratigraphy of Bolivia, B. Geosci., 87, 269-314, 2012.

Richter, R.: Beitrag zur Paläontologie des Thüringer Waldes: Die Grauwacke des Bohlens und des Pfaffenberges bei Saalfeld, Dresden and Leipzig (Arnoldische Buchhandlung), 1-48, 1848.
Shi, C. G.: The Middle and Upper Devonian ostracoda from Dushan and Douyun, Guizhou, Acta Palaeontologica Sinica, 12, 34-59, 1964 (in Chinese with English abstract).

Siveter, D. J.: Ostracods in the Palaeozoic?, Senckenbergiana lethaea, 88, 1-9, 2008.

Sohn, I. G.: New Late Mississippian Ostracode genera and species from Northern Alaska. A revision of the Paraparchitacea, Geological Survey Professional Paper, 711A, 1-24, 1971.

Sohn, I. G.: Late Paleozoic Ostracode species from the conterminous United States, U.S. Geological Survey Professional Paper, 711B, 1-13, 1972.

Song, J. J. and Gong, Y. M.: Ostracods from the Emuha Section of Devonian-Carboniferous transition in Western Junggar, Earth Science-Journal of China University of Geoscience, 40, 797809, 2015a (in Chinese with English abstract).

Song, J. J. and Gong, Y. M.: Progresses and Prospects of Paleozoic ostracod study, Acta Palaeontologica Sinica, 54, 404-424, 2015b (in Chinese with English abstract).

Song, J. J. and Gong, Y. M.: Late Devonian global ostracod palaeobiogeography, Lethaia, 50, 7-25, 2017.

Song, J. J., Crasquin, S., and Gong, Y. M.: Ostracods of the Late Devonian Frasnian/Famennian transition from western Junggar, Xinjiang, NW China, Alcheringa, 41, 250-276, 2017.

Stewart, G. A. and Hendrix, W. E.: Ostracoda of the Olentagy Shale, Franklin and Delaware counties, Ohio, J. Paleontol., 19, 96-115, 1945.

Ulrich, E. O.: New and little known American Paleozoic Ostracoda, Journal of the Cincinnati Society of Natural History, 13, 104137, 1891.

Volk, M.: Das Oberdevon am Schwarzburger Sattel zwischen Südrandspalte und Kamm des Thüringer Waldes, Sitzungsberichte der physikalisch-medizinischen Sozietaet zu Erlangen, 70, 147278, 1939.

Waldschmidt, E.: Über die devonischen Schichten der Gegend von Wildungen, Zeitschrift der deutschen geologischen Gesellschaft, 37, 906-927, 1885.

Walliser, O., Groos-Uffenorde, H., Schindler, E., and Ziegler, W.: On the Upper Kellwasser Horizon (boundary Frasnian/Famennian), Cour. Forsch. Senck., 110, 247-256, 1989.

Wang, J. X.: Frasnian Tentaculites from Yangdi near Guilin City, Acta Micropalaeontologica Sinica, 7, 61-75, 1990.

Wang, S. Q.: Late Permian and Early Triassic Ostracods of Western Guizhou and Northeastern Yunnan, Acta Palaeontologica Sinica, 17, 277-312, 1978 (in Chinese with English abstract).

Wang, S. Q.: Devonian ostracods in Guangxi, Acta Stratigraphica Sinica, 3, 143-146, 1979 (in Chinese with English abstract).

Wang, S. Q.: Late Devonian pelagic ostracod sequences in Luofu region of Guangxi, Chinese Sci. Bull., 4, 234-236, 1983 (in Chinese with English abstract).

Wang, S. Q.: Pelagic Ostracods from Givetian to Tournaisia in South China, Memoir of Nanjing Institute of Geology and Palaeontology Academy Sinica, 9, 1-80, 1984 (in Chinese with English abstract).

Wang, S. Q.: Discovery of Devonian Entomozoids (ostracoda) from southern Guizhou and its significance, Acta Micropalaeontologica Sinica, 3, 81-88, 1986 (in Chinese with English abstract).

Wang, S. Q.: Entomozoids (ostracoda) from upper Devonian at Hanshan section of Longlin, Guangxi, Acta Palaeontologica Sinica, 26, 306-316, 1987 (in Chinese with English abstract). 
Wang, S. Q.: Late Paleozoic ostracode associations from South China and their paleoecological significance, Acta Palaeontologica Sinica, 27, 91-102, 1988 (in Chinese with English abstract).

Wang, S. Q.: Palaeozoic Entomozoacea and Leperditicopida (ostracoda), Fossil Ostracoda of China, Vol. 3, University of Science and Technology of China Press, Hefei, 1-251, 2009 (in Chinese).

Wang, S. Q. and Cao, M. Z.: Devonian Ostracods from Dacaozi Section of Ninglang, Yunnan - Podocopids, Acta Micropalaeontologica Sinica, 14, 460-474, 1997 (in Chinese with English abstract).

Wang, S. Q. and Liu, Z. M.: Leperditiids (ostracoda) from Cuifengshan section, Qujing, Yunnan and their stratigraphical significance, Acta Palaeontologica Sinica, 33, 140-155, 1994 (in Chinese with English abstract).

Wang, S. Q. and Ma, X. P.: Late Devonian benthic ostracodes at the Xikuangshan section of Hunan and their mass extinction, Acta Palaeontologica Sinica, 46, 1-32, 2007 (in Chinese with English abstract).

Wang, S. Q. and Peng, J. L.: Biostratigraphical significance of the Devonian Sinoleperditiini (Ostracoda), Sci. China Ser. D, 35, 263-267, 2005 (in Chinese).

Wang, S. Q. and Shi, C. G.: Middle Devonian ostracoda from Xiangzhou and Wuxuan Districts of Guangxi, Memoir of Nanjing Institute of Geology and Palaeontology Academy Sinica, 5, 83154, 1982 (in Chinese with English abstract).

Wang, S. Q., Liu, Z. M., and Li, Z. B.: Late Silurian and Early Devonian ostracodes from the Qujing area, Yunnan, Acta Micropalaeontologica Sinica, 9, 363-389, 1992 (in Chinese with English abstract).
Wei, M.: Systematic palaeontology-Ostracoda, in: Devonian Stratigraphy, Palaeotology and Sedimentary Facies of Longmenshan, Sichuan, edited by: Hou, H. F., Geological Publishing House, Beijing, 277-314, 1988 (in Chinese with English summary).

Wei, M., Jiang, Z. W., Xie, L. C., and Li, Y. W.: Palaeontological Atlas of Southwest China- Micropalaeontology VolumesOstracods, Geological Publishing House, Beijing, 1-810, 1983 (in Chinese).

Zhang, J. J.: Some ostracods of the Upper Member of Xikuangshan Group of Upper Devonian in central Hunan, Hunan Geology, 5, 57-62, 1986 (in Chinese with English abstract).

Zhang, J. J.: Ostracodes from the Shetianqiao Formation (Upper Devonian), Xiangxiang County, Hunan, Acta Micropalaeontologica Sinica, 12, 167-187, 1995 (in Chinese with English abstract).

Zheng, S. Y.: Some Silurian and Devonian Ostracodes from Jiangyou, Sichuan, Acta Palaeontologica Sinica, 21, 352-361, 1982 (in Chinese with English abstract).

Zong, P., Ma, X. P., Xue, J. Z., and Jin, X. C.: Comparative study of Late Devonian (Famennian) brachiopod assemblages, sea level changes, and geo-events in northwestern and southern China, Palaeogeogr. Palaeocl., 448, 298-316, 2015. 